\title{
Permafrost and Periglacial Processes
}

\section{Recent advances in paleoclimatological studies of Arctic wedge- and pore-ice stable-water isotope records}

\begin{tabular}{|r|l|}
\hline Journal: & Permafrost and Periglacial Processes \\
\hline Manuscript ID & PPP-19-0050.R2 \\
\hline Wiley - Manuscript type: & Special Issue Paper \\
\hline Aute Submitted by the & 21-Feb-2020 \\
\hline Complete List of Authors: & $\begin{array}{l}\text { Porter, Trevor; University of Toronto - Mississauga } \\
\text { Opel, Thomas; Alfred Wegener Institute Helmholtz Centre for Polar and } \\
\text { Marine Research }\end{array}$ \\
\hline Keywords: & $\begin{array}{l}\text { ice wedges, pore ice, syngenetic permafrost, water isotopes, } \\
\text { paleoclimatology }\end{array}$ \\
\hline &
\end{tabular}

\section{SCHOLARONE \\ Manuscripts}


1 Recent advances in paleoclimatological studies of Arctic wedge- and pore-ice stable-water

2 isotope records

3

4 Trevor J. Porter ${ }^{1}$ \& Thomas Opel 2,1

5 'Department of Geography, University of Toronto - Mississauga, Mississauga, ON, L5L 1C6,

6 Canada

$7 \quad{ }^{2}$ Alfred Wegener Institute, Helmholtz Centre for Polar and Marine Research, Telegrafenberg

8 A45, 14473 Potsdam, Germany

9

10 Abstract

11 Late Pleistocene and Holocene ground ice are common throughout the Arctic. Some forms

12 of relict ground ice preserve local meteoric water, and their stable oxygen- and hydrogen-

13 isotope ratios can be used to reconstruct past air temperatures. In this paper, we review the

14 formation and sampling of two forms of relict ground ice - wedge ice and pore ice - and

15 recent (2010-2019) advances in paleoclimatological studies of ground-ice stable-isotope

16 records in the Arctic. Recent advances are attributed to better chronological constraints and

17 refined understandings of the systematics and seasonality of relict wedge ice and pore ice. A

18 rich network of ice-wedge records has emerged, primarily from the Siberian Arctic, whereas

19 pore-ice records are less common. The ice-wedge network depicts a robust pattern of late

20 Pleistocene cooling, and remarkably similar temperature depressions during Marine Isotope

21 Stages 3 and 2. Very high-resolution wedge- and pore-ice stable isotope chronologies have

22 been established recently and used to reconstruct winter and summer climate histories and

23 assess seasonal dependencies in insolation-forced climate. Reports of ancient (>125 ka BP)

24 ground ice demonstrate the long-term persistence of relict ground ice, and its potential to

25 expand our knowledge of Quaternary climate dynamics in the terrestrial Arctic.

27 Keywords: ice wedges; pore ice; syngenetic permafrost; water isotopes; paleoclimatology 


\section{Introduction}

Permafrost not only responds to and drives climate change but provides an extraordinary archive preserving fossils and other natural indicators of environmental and climatic change. Sedimentation and freezing processes, temperature and hydroclimate, and the origin and evolution of permafrost landscapes over millennia can be reconstructed from a suite of natural indicators including: (i) sediments ${ }^{1,2}$; (ii) cryostructures ${ }^{3}$; (iii) molecular-, micro- and macro-fossils ${ }^{4-7}$; and (iv) geochemistry of relict ground ice ${ }^{8,9}$. This review focuses on the stable-isotope geochemistry of relict ground ice, specifically ice wedges and intra-sedimental pore ice, which offer the most promise for paleoclimate studies.

Precipitation ${ }^{18} \mathrm{O} /{ }^{16} \mathrm{O}$ and ${ }^{2} \mathrm{H} /{ }^{1} \mathrm{H}$ isotope ratios (hereafter $\delta^{18} \mathrm{O}_{\text {precip }}$ and $\delta^{2} \mathrm{H}_{\text {precip }}$ ) are sensitive proxies for air temperature at mid- to high-latitude regions ${ }^{10}$ and can be preserved in relict ground ice for millennia. Ice wedges preserve cold-season precipitation that is integrated as meltwater that fills the cavity of thermal contraction cracks in spring ${ }^{11}$. As such, ice wedges offer a paleoclimate archive that specifically reflects winter conditions. . Structureless, interstitial pore ice originates from active-layer waters that froze in situ ${ }^{3}$, and can integrate a blend of warm-season or annual precipitation depending on local climate and soil properties and, therefore, has a less specific seasonality than wedge ice. Nevertheless, pore-ice waterisotope ratios can be used to constrain past climate changes ${ }^{12,13}$.

The association between precipitation isotopes and temperature ${ }^{10}$ was first exploited by the glacial ice-core community for paleoclimate reconstruction more than a half-century ago ${ }^{14}$, and has since been applied to different forms of relict ground ice ${ }^{15,16}$. Within the ice-core community, a relatively unified framework has emerged for quantitative climate reconstruction using stable-water isotopes ${ }^{17}$. Conversely, paleoclimate inferences from ground-ice stable-isotope records have generally been more qualitative (i.e., warmer vs. colder $^{18}$. This tendency toward a more qualitative approach in the permafrost community may relate to challenges with the dating of relict ice, and proxy-climate uncertainties related 
57 to the precipitation-isotope system and the systematics of different forms of ground ice, all of 58 which have some bearing on the fidelity of climate reconstructions.

60 Despite of these challenges, there is growing interest in the potential to use wedge- and 61 pore-ice isotope records to constrain Quaternary climates in the unglaciated Arctic. This 62 interest has increased the number of researchers participating in this field, and encouraged 63 the generation of more quantitative datasets for use by the broader paleoclimate community 64 in data-model comparisons ${ }^{19}$ and their inclusion in paleoclimate databases ${ }^{20,21}$. Careful 65 attention to these broader applications of ground-ice stable isotope records will ultimately 66 increase the visibility of this field. In this paper, we review recent (2010-2019) advances in 67 wedge- and pore-ice stable isotope studies in the Arctic (Fig. 1) and complement earlier 68 reviews on the physics of ground ice formation ${ }^{22}$, regional ice-wedge syntheses ${ }^{23}$ and the 69 scientific methods of ice-wedge paleoclimatology ${ }^{11}$. We start with a brief summary outlining 70 the formation and preservation of meteoric waters in wedge ice and pore ice, and 71 methodological topics including sampling and dating that have implications for the 72 interpretation of relict ice records. Second, we present a meta-analysis of wedge-ice $\delta^{18} \mathrm{O}$ 73 data from 82 Northern Hemisphere sites (Fig. 1) and discuss the climatic origin of spatial 74 patterns during the late Pleistocene and Holocene. Lastly, we review recent progress in 75 paleoclimate knowledge gained from wedge- and pore-ice isotope records from a selection 76 of studies located throughout the Arctic that highlight the diversity of insights these types of 77 records offer the paleoclimate community.

\section{FIGURE 1 HERE}

80 Figure 1. Sites of recent studies of water isotopes in relict wedge ice (yellow circles) and 81 pore ice (red squares); Russian sub-regions of W. Siberia (R1), Laptev Sea region (R2), 82 Kolyma and Chukotka (R3) and central Yakutia (R4) are indicated; modelled permafrost 83 zones $^{24}$ are indicated. 


\section{Systematics of relict wedge- and pore-ice formation}

\subsection{Wedge ice}

Ice wedges form in polygonal patterns and grow due to the repetition of wintertime thermal contraction cracking of the ground, and the filling of frost cracks in spring ${ }^{25}$. Melt water from the winter snowpack is assumed to be the major constituent for filling frost cracks. It integrates the isotopic composition of winter precipitation and refreezes immediately in the crack to form an ice vein. According to Michel26 this rapid freezing is a non-equilibrium freezing process with no or only insignificant isotopic fractionation. Minor contributions of hoar frost and dry snow, and detrital sediment and organic material washed into the crack by snowmelt may also contribute to ice veins.

Recent studies of ice crystallography, water isotopes and the composition and shape of gas bubbles, however, challenge this general assumption. St-Jean et al. ${ }^{27}$ proposed that climate and site-specific conditions may determine the mode of ice wedge formation, with re-frozen snowmelt being more common in warm-wet environments, and hoar frost accretion/dry snow densification more common in cold-dry environments. They determined that the gas bubbles which form in ice wedges derived from hoar frost and dry snow are more spherical than the gas bubbles that form in a freezing liquid. Trace-gas concentrations of the bubbles also differ depending on the mode of ice formation ${ }^{27}$. These observations suggest that relatively simple physical measurements can be used to differentiate between genetic classes of wedge ice, which may hold value in refining paleoclimate interpretations of wedge-ice water-isotope data. Based on studies of both Pleistocene and Holocene ice wedges in Siberia, Boereboom et al. ${ }^{28}$ emphasizes that crack-infilling material is a variable water-snow mix with a tendency toward higher proportions of snowmelt during warmer periods (e.g., Holocene), whereas Kim et al. ${ }^{29}$ even exclude the participation of a liquid water phase in forming the studied late Pleistocene Marine Isotope Stage (MIS) 2 ice wedges in Central Yakutia. 
112 Irrespective of the composition of the frost-crack infill material, it is evident that ice wedges

113 originate from winter precipitation and, therefore, their stable-isotope composition represents

114 a cold-season temperature signal.

\subsection{Pore ice}

117 In syngenetic permafrost, pore ice preserves precipitation or runoff that percolated through

118 the active layer during past thaw seasons, froze at or near the permafrost table during the

119 freeze-back period, and later became relict (i.e., fell below the permafrost table) following

120 permafrost aggradation due to accumulation of surface materials. The pore waters that form

121 pore ice may integrate (i) meltwater derived from snow and active-layer pore ice that formed

122 during previous years, and (ii) warm-season precipitation that can penetrate the full depth of

123 the active layer. The seasonality of precipitation in pore ice depends on local climatological

124 factors such as mean air temperatures and monthly precipitation totals, as well as the

125 thermal and hydraulic properties of the ground. For example, at a sloped peat plateau site in 126 central Yukon, Porter et al. ${ }^{13}$ found that ca. modern (last decade) pore ice integrated a multi-

127 annual blend of primarily summer precipitation. They attributed this seasonality to (i) low

128 permeability of the ice-rich peats to snowmelt at the start of the thaw season; (ii) efficient

129 drainage of springtime precipitation as active layer runoff due to a higher saturated hydraulic 130 conductivity at shallow thaw depths, (iii) a climatological bias with warm-season precipitation 131 (mostly rain) accounting for roughly two-thirds of the annual precipitation budget, and (iv) a 132 greater active layer thickness in the late summer that allows summer precipitation to reach 133 the permafrost table where it has the potential to become relict pore ice. However, reports on 134 the isotopic composition of pore ice from other northern sites indicate that pore ice can take 135 on more of an annual seasonality ${ }^{30}$, suggesting that site-specific conditions play an important 136 role in determining the precipitation seasonality of relict pore ice.

138 In contrast to wedge ice, the relatively slow rates of freezing that occur in the active layer 139 during the freeze-back causes pore water isotopes to fractionate between the liquid and 
140 solid phase, with a preference for heavy isotopologues $\left({ }^{1} \mathrm{H}^{2} \mathrm{H}^{16} \mathrm{O}\right.$ and $\left.{ }^{1} \mathrm{H}_{2}{ }^{18} \mathrm{O}\right)$ in the solid

141 phase ${ }^{31}$. Assuming the range of experimentally constrained fractionation factors, the overall

$142 \delta^{18} \mathrm{O}$ enrichment of ice above water $\left(\varepsilon^{18} \mathrm{O}_{\mathrm{i}-\mathrm{w}}\right)$ is expected to be $\sim 2.7-3.1 \%$ o under equilibrium

143 conditions (slow freezing rate and unimpeded molecular diffusion) ${ }^{31}$. However, $\varepsilon^{18} \mathrm{O}_{\mathrm{i}-\mathrm{w}}$ values

144 as low as $0.8-1.0 \%$ have been observed in natural active layers which suggests that non-

145 equilibrium freezing conditions are common ${ }^{13,32}$. Since cryofractionation depends on rates of

146 thermal and molecular diffusion, a constant $\varepsilon_{\mathrm{i}-\mathrm{w}}$ may be a reasonable assumption for any

147 given sequence of syngenetic pore ice if the thermal and hydraulic properties of the paleo-

148 active layer were constant. If a constant $\varepsilon_{i-w}$ is valid, as argued in some studies ${ }^{13}$, it follows

149 that stratigraphic isotope variations in syngenetic pore ice can be used as a first-order proxy

150 for the isotopic composition of precipitation and climate. However, for permafrost sequences

151 where paleo-active layer freezing conditions and $\varepsilon_{i-w}$ may have varied through time (e.g., due

152 to a changing sedimentology and/or porosity), it may be more difficult to resolve the separate

153 effects of changing $\varepsilon_{i-w}$ versus paleoclimate in the isotope stratigraphy of pore ice records.

155 3. Paleoclimate inferences from wedge- and pore-ice

156 Ice wedges have been widely used to reconstruct winter climate changes across Siberia on

157 centennial to glacial/interglacial timescales ${ }^{8,9,15}$, whereas paleoclimate estimates based on

158 intra-sedimental pore ice has been investigated only in some pioneer studies ${ }^{12,13,30}$. Several

159 quantitative transfer functions have been developed to estimate past air temperatures based

160 on wedge- and pore-ice isotope ratios, using either the relation between regional climate and

161 isotope data from modern ice wedges or modern precipitation (see Opel et al. ${ }^{11}$ for a

162 compilation and discussion of transfer functions). More commonly, the stable-isotope

163 variations of relict ice wedges are used for qualitative winter temperature inferences ${ }^{18}$.

165 The accuracy of paleotemperature estimates based on isotope trends in relict ground ice

166 depends on the assumptions that the precipitation seasonality of relict ice and the relation

167 between precipitation-isotope ratios and air temperatures were constant. While this is often 
168 assumed for recent timescales, its validity over glacial-interglacial timescales has been 169 debated at length ${ }^{33}$. Under a constant set of ocean-atmosphere boundary conditions, real or 170 apparent changes in precipitation seasonality and temperature-isotope sensitivity are not 171 expected. However, over glacial timescales when the land-ocean configuration (e.g., sea 172 level, ice sheet topography) was different from today with possible differences in moisture 173 source and trajectory of moist air parcels, there is greater potential for non-temperature 174 related effects in the isotope record. Isotope-enabled General Circulation Models provide 175 opportunities to evaluate the physical processes driving precipitation isotopes and potential 176 changes in temperature sensitivity in response to changing ocean-atmosphere boundary 177 conditions $^{34}$.

179 Finally, differences in global ocean volume may also significantly influence ground ice180 isotope records. During the Pleistocene cold stages, the $\delta^{18} \mathrm{O}$ and $\delta^{2} \mathrm{H}$ of the global ocean 181 was more positive than today due to the increased storage of isotopically depleted water on 182 land in polar ice sheets ${ }^{35}$. Quantitative temperature reconstructions based on ice-core $\delta^{18} \mathrm{O}$ 183 records typically correct for changes in seawater ${ }^{17}$. This same approach has been applied in 184 a limited number of pore-ice ${ }^{13}$ and wedge-ice ${ }^{30}$ studies. However, as the isotopic 185 composition of seawater can vary dramatically over relatively short timescales (e.g., MIS 2-1 transition), explicit seawater corrections to ground-ice and ice-core isotope records require 187 good chronological control to determine an appropriate correction. Seawater corrections are 188 crucial for quantitative paleoclimate estimates. Further, comparison of $\delta^{18} \mathrm{O}$ values from relict 189 ice of different ages for qualitative temperature inferences would also benefit from 190 standardizing isotope data to a constant ocean.

\section{Sampling and dating of relict ground ice}

193 As for all paleoclimate archives, precise dating and chronology development is crucial for 194 meaningful paleoclimate reconstruction. Furthermore, criteria for inclusion of paleoclimate 195 records in multi-proxy databases are often tied to chronology characteristics ${ }^{36}$, so recognition 
196

197

198

199

200

201

202

203

204

205

206

207

208

209

210

211

212

213

214

215

216

217

218

219

220

221

222

of ground-ice studies as a subdiscipline of quantitative paleoclimatology will require careful attention to chronological standards set by the broader community. The type of chronology that can be developed for wedge and pore ice depends on the type of samples collected. In general, ice wedges can be dated indirectly by dating the host sediments or dated directly by dating the ice itself, whereas pore ice can only be dated indirectly from the host sediments.

Ice-wedge sampling strategies have evolved over the last two decades. Early studies commonly used only a few samples per ice wedge taken by ice screw, axe or gas-powered drill, while in recent years chainsaws have become the standard tool for fast and defined sampling (Fig. 2A). To account for the growth pattern of ice wedges in both horizontal and vertical dimensions mainly two sampling schemes have been used: either cutting ice blocks (Fig. 2B-C) or defined sampling resolution by cutting thin slices (Fig. 2D). Preferentially large blocks are collected, which are subject to later handling and subsampling in a freezing lab to ensure the highest quality of samples and reduced risk of contamination, and possible identification of individual ice veins for sub-sampling (Fig 2E). Ice wedges are mostly sampled in exposures at coastal, lake or river cliffs or the headwalls of retrogressive thaw slumps. Ice wedge sampling has also been possible in tunnels dug into the permafrost ${ }^{18,37-}$ 39.

\section{FIGURE 2 HERE}

Figure 2. Ice-wedge and pore-ice sampling. (A) Ice-wedge sampling by chainsaw; $(B, C)$ block cuts from an ice wedge; (D) slice cut from an ice wedge; (E) internal foliation of an ice wedge with visible ice veins and sediment and organic inclusions; (F) pore-ice sampling by lateral coring of a permafrost exposure using a hand-held drill; $(G)$ pore-ice sampling by vertical coring into permafrost using a gas-powered drill; and $(\mathrm{H})$ recovering the permafrost core from the 'core catcher'. 
223 Drilling boreholes horizontally (Fig. 2F) or vertically (Fig. 2G-H) into sediment-rich permafrost

224 is the preferred approach for pore-ice studies. Vertical coring includes the time component and is the easiest sampling approach, but it only yields point information which does not necessarily account for complex three-dimensional cryostratigraphy of ice-rich permafrost. Hence, it may be accompanied by discrete sampling of permafrost exposures.

228

Age determination of host sediments has been achieved mostly by radiocarbon dating of associated plant macro-remains or bulk organics ${ }^{13,40,41}$, but also by optically stimulated luminescence $(\mathrm{OSL})$ of quartz grains ${ }^{39}$, infrared stimulated luminescence (IRSL) of feldspar grains $^{9}$, peat radioisotope disequilibrium ${ }^{42,43}$, geochemical fingerprinting or fission-track dating of glass shards in tephra beds ${ }^{44}$, and paleomagnetic dating ${ }^{45}$. For indirect dating of ground ice one has to keep in mind that relict ice wedges and pore ice are younger than the host sediment at the same level. For ice wedges this is due to the downward directed frost crack filling, and for pore ice this is due to the mobility of liquid water in the unfrozen active layer prior to freezing. In both cases the ground ice is hosted in sediments that were deposited sometime before the ice formed. The age offset between the relict ice and the host sediments depends on the cracking depth for ice wedges, or maximum penetration depth of the pore waters in the active layer (i.e., the maximum active layer thickness) for pore ice, as well as the permafrost aggradation rate in syngenetic permafrost systems.

243 The standard approach for direct dating of ice wedges is AMS radiocarbon dating. For most 244 late Pleistocene and Holocene studies plant macrofossils are used ${ }^{9,18,46}$. In recent years, 245 radiocarbon dating of dissolved organic carbon $\left.\left(\mathrm{DO}^{14} \mathrm{C}\right)\right)^{38,47}$ and ${ }^{14} \mathrm{CO}_{2}$ of air bubbles in the 246 wedge ice ${ }^{29,38}$ has been successfully applied.

248 For a late Pleistocene ice wedge in Alaska, Lachniet et al. ${ }^{38}$ showed that $\mathrm{DO}^{14} \mathrm{C}$ and ${ }^{14} \mathrm{CO}_{2}$ ages are younger than the fine-dispersed particulate organic matter and plant-macro 
250 remains and suggested that the first are geologically more reasonable. The temporal limit of

251 the radiocarbon dating method precludes dating of ground ice older than $\sim 50,000$ years

252 (middle-MIS 3). An independent direct dating approach using the ratio of cosmogenic

253 chlorine-36 $\left({ }^{36} \mathrm{Cl}\right)$ to chloride $(\mathrm{Cl}-)$ in wedge ice reaches back to the middle to late

254 Pleistocene ${ }^{48}$, but requires further proof and refinement.

255

256 Further method development and refinement to date old ground ice is needed as it becomes 257 more evident that, despite its susceptibility to climate warming, ice-rich permafrost can be 258 very persistent and survive even several interglacials. Relict ice wedges from Yukon $259(740,000 \pm 60,000 \mathrm{yr} \mathrm{BP})^{44}$ and Bol'shoy Lyakhovsky Island $(\sim 200,000 \mathrm{yr} B P)^{43}$ predate the 260 oldest ice recovered from the base of the Greenland ice sheet ${ }^{49}$ and possibly represent the 261 oldest ice in the Northern Hemisphere. Reliable dating of such ancient permafrost is a 262 precondition to shed light on the controls of such remarkable permafrost persistence. 263

264 The temporal resolution of most relict wedge-ice records is relatively coarse, for example, 265 binned into stratigraphic units or marine isotope stages or sub-stages (e.g., late MIS 3 or 'full 266 glacial' MIS 2). However, there are examples of wedge-ice time-series with exceptionally 267 high temporal-resolution chronologies (e.g., decadal to centennial). Basically two 268 approaches have been successfully utilized to generate these time-series from ice wedges: age-distance interpolation between radiocarbon dated samples within an ice-wedge profile ${ }^{18}$ 270 and combining paired age-isotope information into a composite record ${ }^{8,50}$. However, 271 application of statistical age-distance models for high-resolution ice-wedge chronologies is 272 relatively uncommon as the underlying assumptions of such models (i.e., continuous growth 273 rate and absence of cross-cutting ice veins) are difficult to verify or are often violated on the 274 basis of ${ }^{14} \mathrm{C}$-age reversals ${ }^{38,50}$.

276 Indirect dating of relict pore ice in a syngenetic permafrost sequence has been approximated 277 in two ways. First, stratigraphic association with dated macrofossils ${ }^{16}$ or with geochemically 
278 verified tephra of known age ${ }^{51}$ in the host sediments gives a maximum age constraint on the 279 pore ice. Second, age interpolation using an age-depth model may be constrained by ${ }^{14} \mathrm{C}$ 280 dated macrofossils and other chronological tie-points (e.g., tephra) in the permafrost 281 sequence ${ }^{13}$. This method assumes that the formation of relict pore ice and paleosurface (and 282 paleo-permafrost) aggradation occurred simultaneously, and that the formation depth of 283 relict pore ice (i.e., maximum thaw depth) did not vary much through time ${ }^{13}$. The latter 284 assumption has implications for the interpolated age of the pore ice. For example, given a 285 constant maximum active layer thickness of $60 \mathrm{~cm}$, the age of any relict pore-ice sample in 286 the permafrost sequence will be equal to the age of sediment found $60 \mathrm{~cm}$ above, which can 287 be referenced from the sediment (paleosurface) age-depth model. The youngest 'relict' pore 288 ice, with an approximate age of ca. present day, is found in the uppermost layer of 289 permafrost.

290

\section{Major paleoclimate results since $\mathbf{2 0 1 0}$}

\subsection{Spatial and temporal patterns of ice-wedge $\delta^{18} \mathrm{O}$ data}

293 For a meta-analysis, we have summarized mean ice-wedge $\delta^{18} \mathrm{O}$ data across the northern 294 high latitudes for several periods: MIS 3 (57-29 cal ka BP), MIS 2 (29-11.7 cal ka BP), 295 Holocene (last 11.7 cal ka BP) and modern (last several decades) in order to examine broad 296 297 spatial and temporal patterns (Fig. 3). This extends earlier work ${ }^{23,52,53}$ mainly by including data from Alaska and Canada. In total, we considered ice-wedge $\delta^{18} \mathrm{O}$ records from 82 study 298 sites (Table S1). Although the meta-analysis focuses on the MIS 3-1 and present-day 299 intervals, a few rare examples of older (MIS 7 to 4 ) ice-wedge $\delta^{18} \mathrm{O}$ records are discussed in 300 sections 5.2.2 and 5.2.4. We are aware that (i) climate was not constant during all four 301 intervals, (ii) mean $\delta^{18} \mathrm{O}$ data of the ice wedges may represent only part of these periods, and (iii) dating uncertainties exist for the ice wedges and host sediments, respectively. Even 303 though these issues add a certain degree of uncertainty, robust spatial and temporal 304 patterns are evident in the ice-wedge $\delta^{18} \mathrm{O}$ data from which general conclusions can be 305 drawn. 


\section{FIGURE 3 HERE}

308 Figure 3. Average wedge-ice $\delta^{18} \mathrm{O}$ values dating to (a) modern, (b) Holocene, (c) MIS 2 and 309 (d) MIS 3 from studies since 2010 (see Table S1 for data and sources); Russian sub-regions 310 of W. Siberia (R1), Laptev Sea region (R2), Kolyma and Chukotka (R3) and central Yakutia 311 (R4) are indicated.

$313 \delta^{18} \mathrm{O}$ data of ca. modern ice wedges (Fig. 3a), i.e. those which formed in the last several 314 decades according to stratigraphic interpretation or post-bomb isotope data (e.g., ${ }^{14} \mathrm{C}$ or $\left.{ }^{3} \mathrm{H}\right)$, 315 are most enriched and in most cases exceed the mean Holocene $\delta^{18} \mathrm{O}$ values (Fig. 3b) by 316 several permil. This reflects recent Arctic warming which is particularly evident in the 317 extended winter season as also shown in temperature reconstructions based on ice wedges 318 (Fig. 4a). Holocene wedge-ice $\delta^{18} \mathrm{O}$ mean values are clearly enriched over late Pleistocene 319 wedge-ice $\delta^{18} \mathrm{O}$ mean values of MIS 3 (Fig. 3d) and MIS 2 (Fig. 3c) which reflect a colder 320 mean winter climate during past stadials and interstadials in comparison to the present 321 interglacial. MIS 3 and MIS 2 are characterized by similar wedge-ice $\delta^{18} \mathrm{O}$ values, with only a 322 few surprising exceptions for sites that show lower $\delta^{18} \mathrm{O}$ values during MIS 3 than MIS 2. In 323 the circum-Arctic, the MIS 3 interstadial is often assumed to represent a milder but also more variable climate than the full glacial conditions of MIS 2 that culminated in the Last Glacial 325 Maximum (LGM) at $\sim 21 \mathrm{ka} \mathrm{BP}^{19}$. This apparent discrepancy may be due in part to the winter 326 seasonality of ice wedges and/or to the time integrated in MIS 3 and MIS 2 ice wedges. For 327 example, some MIS 2 ice wedges capture the deglacial period ${ }^{18}$, but almost certainly do not 328 represent the extreme cold or LGM conditions of MIS 2. Further, some areas show a general 329 absence of MIS 2 ice wedges dating to the full glacial ${ }^{30,47}$, which may indicate conditions that 330 inhibited the development (e.g., thicker snow ${ }^{16}$ ) or preservation of ice wedges. A lack of MIS 3312 ice wedges is also observed in parts of the Russian Arctic, where MIS 2 full glacial 332 permafrost deposits (i.e. Sartan Yedoma Ice Complex) may have formed only in specific 333 environments such as river valleys ${ }^{40}$. MIS 2 ice wedges from such Ice Complex deposits on 
334 Bol'shoy Lyakhovsky Island, for example, show extremely depleted $\delta^{18} \mathrm{O}$ values as low as $33537 \%$ (or $6 \%$ lower than MIS 3 ice wedges), while MIS 2 ice wedges from other sites in the 336 Laptev Sea region do not show more depleted $\delta^{18} \mathrm{O}$ values compared to MIS $3^{40}$.

338 Spatial patterns in ice-wedge $\delta^{18} \mathrm{O}$ are evident in all time slices from modern to MIS 3 (Fig.

3393 3) and are generally consistent with those of modern winter precipitation isotopes ${ }^{54}$. Coastal 340 ice wedges are more enriched in $\delta^{18} \mathrm{O}$ compared to more continental ice wedges, likely

341 reflecting the smaller distance to the moisture source. A remarkable feature is the zonal $\delta^{18} \mathrm{O}$ 342 trend across the coastal Russian Arctic with $\delta^{18} \mathrm{O}$ values decreasing from west to east. This 343 pattern likely reflects a dominance of westerly moisture transport from the North Atlantic and 344 Rayleigh distillation along a west-east temperature gradient that was a constant feature of 345 the last $\sim 60 \mathrm{kyr}$, independent of climate and ice-sheet configuration. Study sites in Chukotka 346 in easternmost Russia show more enriched values and reflect mainly Pacific moisture 347 sources 55 .

349 This spatial analysis is somewhat limited by the fact that most ice-wedge study sites are 350 located in the Russian Arctic and/or along the coast, whereas the North American Arctic 351 sites are too sparsely distributed to resolve regional spatial trends.

\subsection{Major paleoclimate results from Russian Arctic sites}

354 Studies of relict ground ice for paleoenvironmental reconstruction in the Russian high 355 latitudes date back more than three decades ${ }^{15}$ and have led to a remarkable collection of 356 data. . In the following sections we briefly review major progress over the last 10 years in 4 357 main regions (West Siberia, Laptev Sea region, Kolyma region and Chukotka) and Interior 358 Yakutia. 359

\subsubsection{West Siberia}


361 Only a few studies exist for West Siberia. Based on syngenetic ice wedges of MIS 2 and

362 Holocene age at three sites at the eastern coast of the Yenisei Bay (Western Taymyr

363 Peninsula), Streletskaya et al. ${ }^{56}$ demonstrate that this part of the Taymyr Peninsula was not

364 glaciated during the LGM. The authors infer warming since the MIS 2, with mean $\delta^{18} \mathrm{O}$

365 values of about $-26 \%$ during MIS 2 increasing to Holocene mean $\delta^{18} \mathrm{O}$ values of $-20.5 \%$.

366 Modern ice wedges are even more enriched above the Holocene wedges by a similar

367 amount, with a $\delta^{18} \mathrm{O}$ value of about $-16.5 \%$. For the MIS 2 ice wedges, Streletskaya et al. ${ }^{56}$

368 estimated a mean January temperature of around $-40^{\circ} \mathrm{C}$, which is $12-15^{\circ} \mathrm{C}$ colder than at

369 present. The increase in $\delta^{18} \mathrm{O}$ is accompanied by an increase in $d_{\text {excess }}\left(\delta^{2} \mathrm{H}-8 \times \delta^{18} \mathrm{O}\right)$ from

370 mean values of $\sim 8-9 \%$ to $\sim 11-13 \%$. Similar $\delta^{18} \mathrm{O}$ values for Holocene and modern ice

371 wedges are observed on the Southern Yamal Peninsula ${ }^{57}$.

372

373 Given its proximity to the western boundary of the permafrost zone and to the Barents and

374 Kara seas, which both are particularly affected by modern and likely also past Arctic climate

375 and sea-ice changes, West Siberia may be a key region for future detailed ice-wedge

376 paleoclimate studies.

377

$378 \quad$ 5.2.2 Laptev Sea region

379 Over the last decades the Laptev Sea region has been one of the main study regions for

380 relict permafrost in the Russian Arctic. The late Pleistocene Yedoma Ice Complex of MIS 3

381 to 2 age and its degradation forms (i.e., thermokarst basins) are major landform elements in

382 the coastal lowlands of the region. However, at the Dmitry Laptev Strait two older Ice

383 Complex units have been studied, dating to MIS $7^{43}$ and MIS $5^{42}$.

384

385 Three Ice Complex units share similar mean wedge-ice $\delta^{18} \mathrm{O}$ values: MIS $7(-32 \%)$, MIS 5 ($38633 \%)$ and MIS $3(-31 \%$ ) indicating comparable winter temperatures during the MIS 7

387 interglacial and the MIS 5 and MIS 3 interstadials. In contrast, the MIS 2 Ice Complex is

388 characterized by a mean wedge-ice $\delta^{18} \mathrm{O}$ value of $-37 \%$, indicating significantly colder mean 
389 winter temperatures during the stadial towards the LGM, an unprecedented pattern for the 390 Russian Arctic ${ }^{43}$. It should be noted that the MIS 5 Buchchagy Ice Complex does not capture 391 the globally warm last interglacial period, i.e. MIS $5 \mathrm{e}^{42}$. The thermokarst-lake and 392 thermokarst-basin palustrine deposits of the Krest Yuryakh Suite (formerly attributed to MIS 3935 e) are most likely degradation forms of the Buchchagy Ice Complex. They have been IRSL394 dated to $102.4 \pm 9.7 \mathrm{ka}^{9}$, placing them within the MIS $5 \mathrm{~d}$ stadial. Further dating and isotopic 395 studies are necessary to solve this puzzle of Northeast Siberian climate and landscape 396 dynamics.

397

398 Interestingly, the mean $d_{\text {excess }}$ values are quite similar across all four Ice Complex units, 399 indicating similar atmospheric moisture generation and transport patterns in winter ${ }^{43}$. Cold 400 stage conditions similar to the MIS 2 are reflected by mean ice-wedge $\delta^{18} \mathrm{O}$ values of $-36 \%$ o 401 for MIS 4 ice wedges preserved in floodplain deposits.

402

403 Much warmer winter temperatures can be inferred from Holocene (mean $\delta^{18} \mathrm{O}$ of $-25 \%$ ) and 404 in particular modern (mean $\delta^{18} \mathrm{O}$ values of $-20.5 \%$ ) ice wedges, clearly reflecting the 405 interglacial Holocene and recent Arctic warming 9 . Winter temperature trends at higher (i.e. 406 centennial) resolution have recently been obtained from Holocene ice wedges preserved in 407 river terraces and on top of the Yedoma Ice Complex in the Lena Delta ${ }^{8}$. A composite 408 wedge-ice $\delta^{18} \mathrm{O}$ record from the Lena Delta ${ }^{8}$, based on paired ${ }^{14} \mathrm{C}$ ages and $\delta^{18} \mathrm{O}$ data of 42 409 ice-wedge samples, and additionally modern ice wedges, shows a long-term $\delta^{18} \mathrm{O}$ increase $410\left(\Delta \delta^{18} \mathrm{O}=+0.45 \%{ }^{\circ} \mathrm{ka}^{-1}\right)$ until $\mathrm{AD}$ 1850. It indicates a warming trend in winter (December to 411 May) that began as early as the mid-Holocene, which has been followed by unprecedented 412 warming in the last $\sim 150$ years (Fig. 4a). This first evidence of a Holocene winter warming 413 trend differs from long-term cooling seen in most other high-latitude temperature proxies that 414 are biased towards the summer and are driven by declining summer insolation. In contrast, 415 the cold-season warming may be largely explained by long-term increases in cold-season 416 (November to April) insolation (Fig. 4b) and greenhouse gas forcing. The Holocene winter 
417 warming is corroborated by paleoclimate model simulations ${ }^{8}$. While the Lena Delta record

418 does not show a significant trend over the last two millennia, except for the unprecedented

419 recent warming, a second record from a drained thermokarst basin at the Oyogos Yar

$420 \operatorname{coast}^{50}$ shows a pronounced warming trend over this period and the modern era $\left(\Delta \delta^{18} \mathrm{O}=\right.$

$421+1.5 \%{ }^{\circ} \mathrm{ka}^{-1}$ ) (Fig. 4a). The warming towards present conditions is detectable in the high-

422 resolution stable-isotope profiles from all three ice wedges studied at this site.

423

424 FIGURE 4 HERE

425 Figure 4. Holocene paleoclimate reconstructions and relict ground-ice water-isotope

426 records. (a) Multi-site stacked wedge-ice $\delta^{18} \mathrm{O}$ record from the Lena Delta ${ }^{8}$ (black dashed

427 line) and a single-site stacked wedge-ice $\delta^{18} \mathrm{O}$ record from the Oyogos Yar $\operatorname{coast}^{50}$ (red

428 dashed line); (b) insolation change relative to modern during the warm-season (Jun-Sep)

429 and cold-season (Nov-Apr) after Laskar et al. 58 ; (c) pore-ice $\delta^{2} \mathrm{H}$ record from DHP174 site in

430 central Yukon ${ }^{13}$; (d) Northern Hemisphere multi-proxy temperature reconstruction ${ }^{59}$.

431

$432 \quad$ 5.2.3 Kolyma region and Chukotka

433 The lower reaches of the Kolyma River have been an important region for ice-wedge

434 paleoclimate research ${ }^{15}$. At different sites along the roughly $10 \mathrm{~km}$-long exposure of the

435 Duvanny Yar Ice Complex key site (MIS 3 to MIS 2), vertical $\delta^{18} \mathrm{O}$ profiles vary between

436 about -33 and $-30 \%$, partly in a cyclic pattern and slightly decreasing upwards ${ }^{2}$. Vasil'chuk ${ }^{60}$

437 interpreted some of the spiky maxima in the Duvanny Yar and other regional ice-wedge sites

438 as possible Dansgaard-Oeschger events, decadal- to multi-decadal climate oscillations of

439 the North Atlantic sector during MIS 3, as observed in Greenland ice cores ${ }^{61}$. However, the

440 relatively coarse dating and dating uncertainties of the Duvanny Yar isotope stratigraphy

441 makes attribution to any specific Dansgaard-Oeschger event difficult. If Dansgaard-

442 Oeschger events are truly represented in the Kolyma region this would have major

443 implications for our understanding of the role the North Atlantic Thermohaline Circulation

444 plays in regulating broader scale climate variability across the Arctic. At the Plakhinskii Yar 
445 Ice Complex site, a vertical ice-wedge profile covering the latest MIS 3 and full MIS 2 ( $\sim 30$ $44612 \mathrm{ka}$ ) reveals a larger $\delta^{18} \mathrm{O}$ variability ranging from -34.7 to $-30 \% 0^{62}$. The coldest period in 447 the record (30-28 ka) is attributed to Heinrich Stadial 3. Another cold period around 18-16 ka 448 reaches similarly depleted values, followed by a warming $\left(\delta^{18} \mathrm{O}\right.$ values between -31 and $44930 \%$ ). In contrast to these sites, the wedge-ice $\delta^{18} \mathrm{O}$ profile of the Stanchikovsky Yar Ice 450 Complex suggests stable climate conditions between 35 and $25 \mathrm{ka}^{63}$. The Ice Complex at 451 Ayon Island in Kolyma Bay shows rather variable wedge-ice $\delta^{18} \mathrm{O}$ values between -34 and $45229 \%$ for the period 30 to 10 ka with lower values in the first half of the record, whereas 453 Holocene ice wedges reflect much higher temperatures with a mean $\delta^{18} \mathrm{O}$ value of $-21.6 \% 0^{64}$. 454

455 Distinctly more enriched $\delta^{18} \mathrm{O}$ values ranging from -29 to $-26 \%$ are observed in a vertical 456 ice wedge profile dated to 42 to $27 \mathrm{ka}$ at the Ledovy Obrykh site in the Mayn River valley in 457 Chukotka ${ }^{65}$. An upwardly decreasing trend during the MIS 3 to 2 transition was interpreted 458 as a cooling trend. Again, Holocene wedge ice at this site is substantially enriched in $\delta^{18} \mathrm{O}$ 459 and yields a mean value of $-20 \%$.

460

461 The East Chukotka Peninsula receives between 40 and $60 \%$ of its precipitation from the 462 Northern Pacific Ocean ${ }^{55}$. Stable isotopes of early and middle Holocene ice wedges at three 463 sites on the East Chukotka Peninsula 55 clearly reflect this proximity to the main moisture 464 source. They are distinctly enriched compared to more continental sites in Chukotka and 465 most other study sites in the Russian High Latitudes, and similar to those from West Siberia. 466 Mean $\delta^{18} \mathrm{O}$ values per wedge vary between $-18.5 \%$ and $-14 \%$. Mean $d_{\text {excess }}$ values are also 467 similar to West Siberia, ranging between 8 and 13\%. Modern ice wedges show more 468 enriched $\delta^{18} \mathrm{O}$ values $(-13 \%)$ and lower $d_{\text {excess }}(6 \%)$, reflecting modern warming and 469 associated changes in moisture generation and transport dynamics. 470 471

\subsubsection{Interior Yakutia}


472 Interior parts of Yakutia are understudied compared to the coastal sites of the Russian

473 Arctic, but there are new ice-wedge stable-isotope data and insights on past winter climate in

474 this highly continental region from the Batagay megaslump in the Yana Highlands.

475

476 Vasil'chuk et al. ${ }^{66}$ and Opel et al..$^{52}$ revealed consistent mean $\delta^{18} \mathrm{O}$ values of around $-35 \%$

477 for several ice wedges of the upper ice complex unit of the slump headwall attributed to the

478 MIS 3 interstadial. Such depleted values have not been observed in other MIS 3 deposits in

479 all of Siberia ${ }^{52,66}$, which suggests this region then had, as it does today, an extreme

480 continental climate (Fig. 3). Additionally, the mean $d_{\text {excess }}$ values of the Batagay and other

481 Central Yakutian sites exhibit the highest mean values $(\geq 8 \%$ ) in comparison to other MIS 3

482 ice wedges across Siberia ${ }^{52}$.

483

484 While no Holocene ice wedges have been found in the Batagay megaslump, a late Holocene

485 ice wedge from nearby at the Adycha River also exhibits more depleted mean $\delta^{18} \mathrm{O}$ values ($48629 \%$ ) compared to other study sites across Siberia indicating the high continentality but

487 similar $d_{\text {excess }}$ values ${ }^{52}$. How exactly the spatial $d_{\text {excess }}$ pattern is influenced by the degree of 488 continentality remains a topic for future studies. Interestingly, the $\delta^{18} \mathrm{O}$ difference between 489 MIS 3 and the Holocene (6\%) is about the same as for the Dmitry Laptev Strait.

490

491 The age of the lower ice complex exposed in the Batagay megaslump is not yet well known.

492 Luminescence ages of $142.8 \pm 25.3 \mathrm{kyr}$ and $>123.2 \mathrm{kyr}(\mathrm{OSL})$ and $210.0 \pm 23.0 \mathrm{kyr}$ (IRSL)

493 for the discordantly overlying lower sand unit suggest that the age of the Lower Ice Complex

494 is MIS 6 or older. It could represent the oldest wedge ice ever analyzed for stable isotopes.

495 Notably, it is clear that this ice complex has survived at least 2 Interglacials (in MIS 5 and

496 Holocene), which demonstrates the local persistence of permafrost under suitable

497 conditions. The mean wedge-ice $\delta^{18} \mathrm{O}$ value of $-33 \%$ reflects a cold winter climate that is

498 comparable, but not as cold as MIS $3^{52}$.

499 
$500 \quad 5.3$ Major paleoclimate results from North American Arctic sites

501 Compared to the Russian Arctic, the western North American Arctic has seen less activity in

502 the study of relict ground-ice stable-isotopes as a paleoclimate proxy, although there is a

503 long history of studies in this region where relict ice stable-isotope records have been used

504 for other purposes such as age and genetic classification of ground ice ${ }^{67,68}$. Nevertheless,

505 there are several relevant studies from the last ten years that have contributed to advances

506 in knowledge of Arctic paleoclimate, mainly from the Yukon-Alaska Arctic coast and

507 continental Yukon-Alaska.

508

$509 \quad$ 5.3.1 Yukon and Alaskan Arctic coasts

510 Studies of relict ice wedges from the Yukon and Alaskan Arctic coasts offer cold-season

511 paleoclimate insights primarily dating to the deglacial phase of MIS 2 and the Holocene.

512

513 Discrete sampling of ice wedges has been reported from several localities along the

514 Canadian western Arctic coast where upper late Pleistocene and Holocene permafrost is

515 exposed. At Herschel Island, which is one of the few Canadian sites where both MIS 2 and

516 Holocene ice wedges are reported, Fritz et al. ${ }^{69}$ found a roughly $7 \%$ increase in mean $\delta^{18} \mathrm{O}$

517 from -29\%o (Wisconsinan deglacial, 16 ka BP) to -22\%o (mid-Holocene) which the authors

518 interpret as due to winter warming. This was validated by a similar mean Holocene value of -

$51923 \%$ for ice wedges at Komakuk Beach $\sim 30 \mathrm{~km}$ west of Herschel Island ${ }^{69}$ and King Point,

$520 \sim 70 \mathrm{~km}$ southwest of Herschel Island ${ }^{70}$. The chronology of the Herschel Island ice wedges,

521 however, is only loosely constrained by the dating of the associated sedimentary units, and

522 so these $\delta^{18} \mathrm{O}$ data are only considered as broadly representative of the MIS 2 deglacial and

523 Holocene periods.

524

525 On the north coast of Alaska near Barrow (Utqiagivik), Meyer et al. ${ }^{18}$ reported a $\sim 3,000$ year-

526 long continuous record of wedge-ice $\delta^{18} \mathrm{O}$ and $d_{\text {excess }}$ from the Barrow Ice Wedge System

527 (BIWS). Importantly, this record provides the only known sequence of wedge-ice $\delta^{18} \mathrm{O}$ 
528 capturing the deglacial transition from the Bølling-Allerød (BA) interstadial to Younger Dryas

529 (YD) stadial conditions $\sim 12.9 \mathrm{ka} \mathrm{BP}$, and the subsequent onset of Preboreal warming at

$530 \sim 11.5 \mathrm{ka}$ BP. A second novel aspect of this record is a companion pollen dataset developed

531 from the host sediments ${ }^{37}$ which allowed the authors to resolve the local paleoecology and

532 summer temperature history, in addition to the winter temperature history, which

533 demonstrates the potential to develop multi-proxy and seasonally holistic records of

534 paleoenvironmental change from ice wedge-bearing permafrost units.

535

536 FIGURE 5 HERE

537 Figure 5. Water isotope and phytoplankton-derived methanesulfonate ion (MS-) records

538 dating to the Younger Dryas transition from the Barrow Ice Wedge System (BIWS) and

539 NGRIP ice core. (a, b) $\delta^{18} \mathrm{O}$ and $d_{\text {excess }}$ records from BIWS ${ }^{18}$ (red circles) and NGRIP71 (black

540 line). (c) MS- ion concentration from BIWS 72 (red circles).

541

542 The BIWS $\delta^{18} \mathrm{O}$ record documents a $\sim 5 \%$ decrease (from $-22 \%$ to $-27 \%$ ) at the BA-YD

543 transition $\sim 12.8 \mathrm{ka} \mathrm{BP}$, which is similar to a $\sim 6 \%$ decrease in the NGRIP (Greenland) ice

544 core $\delta^{18} \mathrm{O}$ record since $\sim 14.5 \mathrm{ka} \mathrm{BP}$ (Fig. 5a). The authors noted that this change in the

545 BIWS record likely represents extreme cooling of local winter conditions, although they did

546 not quantify the magnitude of cooling. After $11.5 \mathrm{ka}$, the formal limit of the YD, the BIWS and

547 NGRIP records both show a rebound to mean $\delta^{18} \mathrm{O}$ values that were more typical during the

548 BA interstadial (Fig. 5a). The coherence of the BIWS and NGRIP records has major

549 climatological implications, and suggests the Arctic system was tightly coupled at broad

550 geographic scales during deglacial times, a conclusion that has since been extended to the

551 North Pacific ${ }^{73}$. Meyer et al. ${ }^{18}$ also observed coherent changes in the BIWS and NGRIP

$552 d_{\text {excess }}$ records (Fig. 5b), implying major changes in moisture source evaporative boundary

553 conditions, but for the BIWS specifically this change was linked to flooding of the Alaskan

554 continental shelf due to deglacial sea level rise. Last, another notable finding from the BIWS

555 is the indication from the companion pollen record that YD summers in that area were not 
556 much colder than today ${ }^{37}$, implying important seasonality differences in the expression of the

557 YD climate event on the Alaskan north coast. This finding of relatively warm summers during

558 a period that is generally thought of as extremely cold is curious, but also finds some support

559 from an independent study by lizuka et al. ${ }^{72}$ that inferred relatively low sea ice

560 concentrations just offshore from the BIWS site during the early YD.

561

562 lizuka et al. ${ }^{72}$ revisited the BIWS and analyzed the wedge ice for marine-derived aerosols,

563 often applied in glacier ice-core studies for reconstructing sea ice concentrations. They

564 observed high methanesulfonate ion $\left(\mathrm{MS}^{-}\right)$concentrations during the early and coldest YD

565 periods, indicating a high marine productivity and, therefore, nearshore open water

566 conditions during the summer in the Beaufort Sea near Barrow, Alaska (Fig. 5c). This novel

567 application of the $\mathrm{MS}^{-}$proxy in ice wedges demonstrates a potentially new direction that can

568 fill gaps in our knowledge of paleo-sea ice conditions in Arctic coastal settings.

569

$570 \quad$ 5.3.2 Continental Alaska and Yukon

571 Recent studies in continental Alaska and Yukon that have used ground ice stable isotope

572 ratios for paleoclimate reconstruction are mostly based on wedge ice ${ }^{30,38,74}$, but also include

573 rare examples where syngenetic pore ice has been used ${ }^{13,30}$.

574

575 At the Fox Creek (CRREL) permafrost tunnel near Fairbanks, Alaska, Lachniet et al. ${ }^{38}$

576 reported $\delta^{18} \mathrm{O}$ values from a single $\sim 1.2 \mathrm{~m}$ wide ice wedge, which likely formed during the full

577 glacial between ca. 28-22 cal ka BP according to modeled ${ }^{14} \mathrm{CO}_{2}$ ages of air bubbles in the

578 ice. Lachniet et al. ${ }^{74}$ observed a mean $\delta^{18} \mathrm{O}$ value of $-27.2 \%$ for the most depleted wedge

579 ice, which they suggested may reflect the coldest conditions of the LGM. Lachniet et al. ${ }^{74}$

580 noted that the LGM mean value is depleted by $5.4 \%$ compared to nearby Holocene ice

581 wedges $\left(\delta^{18} \mathrm{O}=-21.8 \% \text { o }\right)^{75}$, which they equated to a temperature depression of $\sim 17 \pm 3^{\circ} \mathrm{C}$

582 colder than modern assuming a winter $\Delta \delta^{18} \mathrm{O}_{\text {precip }}$-temperature sensitivity of $0.31 \%{ }^{\circ} \mathrm{C}^{-1}$. 
584 From the Klondike area of central Yukon, Porter et al. ${ }^{30}$ reported wedge-ice $\delta^{18} \mathrm{O}$ values of $58529.3 \%$ for the late MIS 3 (ca. 31.9-30.2 cal. ka BP) and $-24.5 \%$ for the late Holocene (ca. 0586500 year BP), respectively. Based on the $4.8 \%$ mean difference between the MIS 3 and late 587 Holocene wedge-ice $\delta^{18} \mathrm{O}$ values (5.5\%o after standardizing for $\delta^{18} \mathrm{O}_{\text {seawater }}$ ) and an assumed $588 \delta^{18} \mathrm{O}_{\text {precip }}-\Delta \mathrm{T}$ sensitivity of $0.41 \%{ }^{\circ}{ }^{\circ} \mathrm{C}^{-1}$, they estimated that MIS 3 winters in the Klondike were $589 \sim 13 \pm 3^{\circ} \mathrm{C}$ colder than modern. This value is similar to the $\sim 17 \pm 3^{\circ} \mathrm{C}$ temperature depression 590 estimated by Lachniet et al. ${ }^{74}$ from LGM wedge ice in central Alaska, implying that extremely 591 cold winter climates prevailed across Eastern Beringia during MIS 3 and 2. Pore ice from the 592 same Klondike deposits, thought to integrate annual precipitation, showed mean $\delta^{18} \mathrm{O}$ values 593 of $-28.0 \%$ and $-22.7 \%$ for MIS 3 and MIS 1 , respectively ${ }^{30}$. Based on the $5.3 \%$ offset $(6.0 \%$ o 594 after standardizing for $\delta^{18} \mathrm{O}_{\text {seawater }}$ ) Porter et al. ${ }^{30}$ estimated mean annual temperatures during 595 MIS 3 were depressed by up to $\sim 15 \pm 3^{\circ} \mathrm{C}$ compared to the Holocene, which is similar to the 596 MIS 3 winter temperature depression inferred based on wedge ice. However, the authors 597 cautioned that paleotemperature estimates based on isotope ratios of pore ice containing an 598 annual mixture of meteoric water are inevitably more sensitive to changes in the precipitation 599 seasonality than relict ice with a more narrowly constrained seasonality (e.g., ice wedges). 600

601 Finally, a study by Porter et al. ${ }^{13}$ reported the first full-Holocene, quantitative summer602 temperature reconstruction based on pore-ice $\delta^{2} \mathrm{H}$ (Fig. 4c) from a $5.3 \mathrm{~m}$ core of syngenetic 603 permafrost below a soligenous peatland site (DHP174 site) in central Yukon. Porter et al. 604 argued that the $\delta^{2} \mathrm{H}$ variable provides a better estimate of paleotemperature compared to $605 \delta^{18} \mathrm{O}$ since the deuterium-rich isotopologue of water (i.e., $\mathrm{HDO}$ ) is less sensitive than $\mathrm{H}_{2}{ }^{18} \mathrm{O}$ 606 to evaporation-related kinetic effects that may occur at the oceanic moisture source, which 607 can otherwise distort the paleoclimate signal recorded in pore ice ${ }^{13}$. The DHP174 pore-ice 608 record integrates mainly summer precipitation (discussed in Section 2.2). After correcting for 609 long-term seawater changes, the DHP174 pore-ice $\delta^{2} \mathrm{H}$ record was used to reconstruct a 61013.6 ka-long summer temperature history assuming the $\Delta \delta^{2} \mathrm{H}_{\text {precip }}$-temperature sensitivity of $611 \sim 1.6 \%{ }^{\circ} \mathrm{C}^{-1}$. The reconstruction shows deglacial warming since $13.6 \mathrm{ka} \mathrm{BP}$ and reaching a 
612 Thermal Maximum at 7.6-6.6 ka BP when summers were $\sim 0.3^{\circ} \mathrm{C}$ warmer than the Holocene 613 mean. A subsequent 6 ka-long cooling trend $\left(-0.16^{\circ} \mathrm{C}\right.$ per ka) was abruptly reversed at the 614 start of the Industrial Era ( 200 years ago) when temperatures began to rise, culminating in 615 the warmest summer climate at present day and exceeding the Thermal Maximum by $\sim 2^{\circ} \mathrm{C}$. 616 General trends in the early, middle and late Holocene portions of the DHP174 pore-ice $\delta^{2} \mathrm{H}$ 617 record are consistent with a multi-proxy composite temperature reconstruction representing 618 the northern extratropical latitudes ${ }^{59}$ (Fig. 4d). Furthermore, apparent coupling between the 619 reconstructed summer temperatures in Yukon and summer (June-Sept.) insolation at $65^{\circ} \mathrm{N}$ 620 (Fig. 4b) implies solar forcing played a major role in driving regional Holocene climate trends. 621 622

\section{Conclusions and outlook}

623 The application of relict ground ice-stable isotopes for paleoclimate studies has advanced 624 significantly in recent years and led to important insights on Quaternary climate dynamics 625 across the Siberian Arctic and W. North American Arctic. Recent progress is clearly related 626 to advances in ground-ice dating methods, development of high temporal-resolution (e.g., 627 centennial to decadal) composite ground-ice isotope time-series and refined frameworks 628 used to interpret these records, but ultimately driven by demand for paleoclimate data from 629 the broader research community to constrain past (and potentially future) Arctic change. 630

631 Future studies are needed to harness the momentum and growing interest in relict ground632 ice stable isotope paleoclimatology, and we recommend the following research directions:

633 - continued advancement of the scientific methods of ground-ice studies, including 634 dating and chronology development;

635 - continued studies on the isotope systematics of relict ground-ice stable isotopes to 636 enable refined interpretations and quantitative paleoclimate estimates ${ }^{11}$; 637 investigate the paleoclimate value of stable water isotopes in other forms of relict 638 ground ice such as segregated ice lenses and buried ice (e.g., icings ${ }^{51}$ and perennial 639 snowbanks ${ }^{76}$ ); 
640

641

642

643

644

645

646

647

648

649

650

651

652

653

654

655

656

657

658

659

660 In summary, recent studies of wedge- and pore-ice stable isotope records have contributed

661 substantially to knowledge of Quaternary climate dynamics in the Arctic. Continued focus on

662 the key research directions outlined above will help this emerging discipline to reach its full

663 potential in the field of Arctic paleoclimate studies.

664

665 Acknowledgements. 
666 The authors thank Christopher Burn and two anonymous reviewers for their comments that 667 improved this paper. T.J. Porter acknowledges the Natural Sciences and Engineering 668 Research Council of Canada (Discovery Grant) for financial support.

669

670 Data availability. Coordinates of study sites, wedge-ice $\delta^{18} \mathrm{O}$ data plotted in Figures 1 and 3 671 and relevant references are provided in Supplementary Table S1.

672

673 References

674 1. Schirrmeister L, Kunitsky V, Grosse G, et al. Sedimentary characteristics and origin of 675 the Late Pleistocene Ice Complex on north-east Siberian Arctic coastal lowlands and $676 \quad$ islands - A review. Quat Int. 2011;241(1-2):3-25.

677 2. Murton JB, Goslar T, Edwards ME, et al. Palaeoenvironmental Interpretation of 678 Yedoma Silt (Ice Complex) Deposition as Cold-Climate Loess, Duvanny Yar, Northeast Siberia. Permafr Periglac Process. 2015;26(3):208-288.

3. French $\mathrm{H}$, Shur Y. The principles of cryostratigraphy. Earth-Science Rev. 2010;101:190-206.

682 4. Zazula GD, Froese DG, Schweger CE, et al. Palaeobotany: Ice-age steppe vegetation 683 in east Beringia. Nature. 2003;423:603.

684 5. Sher AV, Kuzmina SA, Kuznetsova TV, Sulerzhitsky LD. New insights into the 685 686 687 688 Weichselian environment and climate of the East Siberian Arctic, derived from fossil insects, plants, and mammals. Quat Sci Rev. 2005;24(5-6):533-569.

6. Kienast F, Wetterich S, Schirrmeister L, et al. Paleontological records indicate the occurrence of open woodlands in a dry inland climate at the present-day Arctic coast 689 in western Beringia during the Last Interglacial. Quat Sci Rev. 2011;30(17-18):2134690 2159.

691 7. Andreev AA, Schirrmeister L, Tarasov PE, et al. Vegetation and climate history in the 692 Laptev Sea region (Arctic Siberia) during Late Quaternary inferred from pollen 693 records. Quat Sci Rev. 2011;30(17-18):2182-2199. 
694 8. Meyer H, Opel T, Laepple T, Dereviagin AY, Hoffmann K, Werner M. Long-term winter 695 warming trend in the Siberian Arctic during the mid- to late Holocene. Nat Geosci. $696 \quad 2015 ; 8: 122-125$.

697 9. Opel T, Wetterich S, Meyer H, Dereviagin AY, Fuchs MC, Schirrmeister L. Ground-ice 698 stable isotopes and cryostratigraphy reflect late Quaternary palaeoclimate in the 699 Northeast Siberian Arctic (Oyogos Yar coast, Dmitry Laptev Strait). Clim Past. $700 \quad 2017 ; 13: 587-611$.

701 10. Dansgaard W. Stable isotopes in precipitation. Tellus. 1964;16:436-468.

702 11. Opel T, Meyer H, Wetterich S, Laepple T, Dereviagin A, Murton J. Ice wedges as 703 archives of winter paleoclimate: A review. Permafr Periglac Process. 2018;29(3):199209.

705 12. Schwamborn G, Meyer H, Fedorov G, Schirrmeister L, Hubberten H-W. Ground ice 706 and slope sediments archiving late Quaternary paleoenvironment and paleoclimate 707 708 709 710 711

14. Dansgaard W, Johnsen SJ, Møller J, Langway CC. One thousand centuries of 713 climatic record from Camp Century on the Greenland ice sheet. Science. signals at the margins of El'gygytgyn Impact Crater, NE Siberia. Quat Res. 2006;66:259-272.

13. Porter TJ, Schoenemann SW, Davies LJ, Steig EJ, Bandara S, Froese DG. Recent summer warming in northwestern Canada exceeds the Holocene thermal maximum. Nat Commun. 2019;10(1):1631 (1-10).

718 16. Kotler E, Burn CR. Cryostratigraphy of the Klondike "muck" deposits, west-central 719 Yukon Territory. Can J Earth Sci. 2000;37:849-861.

720 17. Stenni B, Masson-Delmotte V, Selmo E, et al. The deuterium excess records of 721 EPICA Dome C and Dronning Maud Land ice cores (East Antarctica). Quat Sci Rev. 
2010;29(1-2):146-159.

723 18. Meyer H, Schirrmeister L, Yoshikawa K, et al. Permafrost evidence for severe winter 724 cooling during the Younger Dryas in northern Alaska. Geophys Res Lett. 2010;37.

725 19. Bartlein PJ, Harrison SP, Brewer S, et al. Pollen-based continental climate 726 reconstructions at 6 and 21 ka: a global synthesis. Clim Dyn. 2011;37:775-802.

727 20. PAGES2k Consortium. A global multiproxy database for temperature reconstructions 728 of the Common Era. Sci Data. 2017;4(170088).

729 21. Konecky B, McKay N, Churakova (Sidorova) O, et al. The Iso2k Database: A global 730 compilation of paleo- $\delta 180$ and $\delta 2 \mathrm{H}$ records to aid understanding of Common Era 731 climate. Earth Syst Sci Data Discuss. 2020:1-49.

732 22. Lacelle D, Vasil'chuck Y. Recent progress (2007-2012) in permafrost isotope 733 geochemistry. Permafr Periglac Process. 2013;24:138-145.

734 23. Streletskaya ID, Vasiliev AA, Oblogov GE, Tokarev IV. Reconstruction of paleoclimate 735 736 of Russian Arctic in the Late Pleistocene-Holocene on the basis of isotope study of ice wedges. Kriosf Zemli. 2015;19:86-94.

737

24. Obu J, Westermann S, Bartsch A, et al. Northern Hemisphere permafrost map based 738 on TTOP modelling for 2000-2016 at 1 km2 scale. Earth-Science Rev. 2019;193:299739 316.

25. Leffingwell E deK. Ground-ice wedges, the dominant form of ground ice on the north coast of Alaska. J Geol. 1915;23:635-654.

742 26. Michel FA. Isotope Investigations of Permafrost Waters in Northern Canada (PhD Thesis). University of Waterloo; 1982.

744 27. St-Jean M, Lauriol B, Clark ID, Lacelle D, Zdanowicz C. Investigation of ice-wedge 745 infilling processes using stable oxygen and hydrogen isotopes, crystallography and occluded gases (O2, N2, Ar). Permafr Periglac Process. 2011;22(1):49-64.

747 28. Boereboom T, Samyn D, Meyer H, Tison J. Stable isotope and gas properties of two 748 climatically contrasting (Pleistocene and Holocene) ice wedges from Cape Mamontov Klyk, Laptev Sea, northern Siberia. Cryosph. 2013;7:31-46. 
750 29. Kim K, Yang J-W, Yoon H, et al. Greenhouse gas formation in ice wedges at Cyuie, central Yakutia. Permafr Periglac Process. 2019;30(1):48-57.

752

30. Porter TJ, Froese DG, Feakins SJ, et al. Multiple water isotope proxy reconstruction of extremely low last glacial temperatures in Eastern Beringia (Western Arctic). Quat Sci Rev. 2016;137:113-125.

31. Lacelle $\mathrm{D}$. On the $\delta 180, \delta \mathrm{D}$ and d-excess relations in meteoric precipitation and 756 during equilibrium freezing: theoretical approach and field examples. Permafr Periglac Process. 2011;22:13-25.

32. Lacelle D, Fontaine M, Forest AP, Kokelj S. High-resolution stable water isotopes as 759 tracers of thaw unconformities in permafrost: A case study from western Arctic Canada. Chem Geol. 2014;368:85-96.

33. Jouzel J. Calibrating the isotopic paleothermometer. Science. 1999;286:910-911.

34. Werner M, Haese B, Xu X, Zhang X, Butzin M, Lohmann G. H218O, HDO and deuterium excess - results from the fully coupled ECHAM5/MPI-OM Earth system model. Geosci Model Dev. 2016;9(2):647-670.

765

35. Schrag DP, Adkins JF, Mclntyre K, et al. The oxygen isotopic composition of seawater 766 during the Last Glacial Maximum. Quat Sci Rev. 2002;21:331-342.

36. Sundqvist HS, Kaufman DS, McKay NP, et al. Arctic Holocene proxy climate database - new approaches to assessing geochronological accuracy and encoding climate variables. Clim Past. 2014;10(4):1605-1631.

37. Meyer H, Schirrmeister L, Andreev A, et al. Lateglacial and Holocene isotopic and 771 environmental history of northern coastal Alaska - Results from a buried ice-wedge

38. Lachniet MS, Lawson DE, Sloat AR. Revised 14C dating of ice wedge growth in 774 interior Alaska (USA) to MIS 2 reveals cold paleoclimate and carbon recycling in ancient permafrost terrain. Quat Res. 2012;78(2):217-225.

39. Schirrmeister L, Andreev A, Wetterich S, et al. Late Quaternary paleoenvironmental records from the Chatanika River valley near Fairbanks (Alaska). Quat Sci Rev. 
2016;147:259-278.

779 40. Wetterich S, Rudaya N, Tumskoy V, et al. Last Glacial Maximum records in $780 \quad$ permafrost of the East Siberian Arctic. Quat Sci Rev. 2011;30:3139-3151.

781 41. Wetterich S, Tumskoy V, Rudaya N, et al. Ice Complex formation in arctic East Siberia 782 during the MIS3 Interstadial. Quat Sci Rev. 2014;84:39-55.

783 42. Wetterich S, Tumskoy V, Rudaya N, et al. Ice Complex permafrost of MIS5 age in the 784 Dmitry Laptev Strait coastal region (East Siberian Arctic). Quat Sci Rev. $785 \quad 2016 ; 147: 298-311$.

786 43. Wetterich S, Rudaya N, Kuznetsov V, et al. Ice Complex formation on Bol'shoy 787 Lyakhovsky Island (New Siberian Archipelago, East Siberian Arctic) since about 200 $788 \quad$ ka. Quat Res. 2019;92:530-548.

789 44. Froese DG, Westgate JA, Reyes A V, Enkin RJ, Preece SJ. Ancient permafrost and a $790 \quad$ future, warmer Arctic. Science. 2008;321:1648.

791 45. Andreev AA, Grosse G, Schirrmeister L, et al. Late Saalian and Eemian 792 palaeoenvironmental history of the Bol'shoy Lyakhovsky Island (Laptev Sea region, 793 Arctic Siberia). Boreas. 2004;33(4):319-348.

794 46. Vasil'chuk YK, van der Plicht J, Jungner H, Sonninen E, Vasil'chuk AC. First direct 795 796 797

47. Grinter M, Lacelle D, Baranova N, Murseli S, Clark ID. Late Pleistocene and Holocene 798 799 ice-wedge activity on the Blackstone Plateau, central Yukon, Canada. Quat Res. 2019;91(1):179-193.

800 48. Blinov A, Alfimov V, Beer $\mathrm{J}$, et al. Ratio of $36 \mathrm{Cl} / \mathrm{Cl}$ in ground ice of east Siberia and its 801 application for chronometry. Geochemistry, Geophys Geosystems. 2009;10(11):1-12.

802 49. NEEM Community Members. Eemian interglacial reconstructed from a Greenland 803 folded ice core. Nature. 2013;493:489-494.

804 50. Opel T, Laepple T, Meyer H, Dereviagin AY, Wetterich S. Northeast Siberian ice 805 wedges confirm Arctic winter warming over the past two millennia. The Holocene. 
806

807

808

809

810

811

812

813

814

815

816

817

818

819

820

821

822

823

824

825

826

827

828

829

830

831

832

833

2017;27(11):1789-1796.

51. Froese DG, Zazula GD, Reyes A V. Seasonality of the late Pleistocene Dawson tephra and exceptional preservation of a buried riparian surface in central Yukon Territory, Canada. Quat Sci Rev. 2006;25:1542-1551.

52. Opel T, Murton JB, Wetterich S, et al. Middle and Late Pleistocene climate and continentality inferred from ice wedges at Batagay megaslump in the Northern Hemisphere's most continental region, Yana Highlands, interior Yakutia. Clim Past. 2019;15:1443-1461.

53. Vasil'chuk Y, Vasil'chuk A. Spatial distribution of mean winter air temperatures in Siberian permafrost at $20-18$ ka BP using oxygen isotope data. Boreas. 2014;43(3):678-687.

54. Bowen GJ, Wassenaar LI, K.A. H. Global application of stable hydrogen and oxygen isotopes to wildlife forensics. Oecologia. 2005;143:337-348.

55. Vasil'chuk YK, Budantseva NA, Farquharson LM, Maslakov AA, Vasil'chuk AC, Chizhova JN. Isotopic evidence for Holocene January air temperature variability on the East Chukotka Peninsula. Permafr Periglac Process. 2018;29(4):283-297.

56. Streletskaya I, Vasiliev A, Meyer H. Isotopic composition of syngenetic ice wedges and palaeoclimatic reconstruction, western Taymyr, Russian Arctic. Permafr Periglac Process. 2011;22(1):101-106.

57. Vasil'chuk YK, Budantseva NA, Christiansen HH, Chizhova JN, Vasil'chuk AC, Zemskova AM. Oxygen stable isotope variation in Late Holocene ice wedges in Yamal Peninsula and Svalbard. Geogr Environ Sustain. 2015;8:36-54.

58. Laskar J, Fienga A, Gastineau M, Manche H. La2010: a new orbital solution for the long-term motion of the Earth. Astron Astrophys. 2011;532:A89.

59. Marcott SA, Shakun JD, Clark PU, Mix AC. A reconstruction of regional and global temperature for the past 11,300 years. Science. $2013 ; 339: 1198-1201$.

60. Vasil'chuk YK. Syngenetic Ice Wedges: Cyclical Formation, Radiocarbon Age and Stable Isotope Records by Yurij K. Vasil ' chuk, Moscow University Press, Moscow, 
834 2006. 404 pp. ISBN 5-211-05212 - 9. Permafr Periglac Process. 2013;24(1):82-93.

835 61. Johnsen SJ, Dahl-Jensen D, Gundestrup N, et al. Oxygen isotope and 836 palaeotemperature records from six Greenland ice-core stations: Camp Century, Dye837 3, GRIP, GISP2, Renland and NorthGRIP. J Quat Sci. 2001;16:299-307.

838 62. Vasil'chuk YK, Vasil'chuk AC. Winter air paleotemperatures at 30-12 kyr BP in the 839 Lower Kolyma River, Plankhinskii Yar Yedoma: Evidence from stable isotopes. $840 \quad$ Earth's Cryosph. 2018;22:3-16.

841 63. Vasil'chuk YK, Budantseva NA, Bartova AV, Zimov SA. Variations of stable oxygen 842 isotopes in ice wedges of the cyclite yedoma of Stanchikovsky Yar on the Maly Anyuy $843 \quad$ River. Arct Antarct. 2018:37-56.

844 64. Vasil'chuk YK, Vasil'chuk AC. The Oxygen Isotope Composition of Ice Wedges of 845 Ayon Island and Paleotemperature Reconstructions of the Late Pleistocene and 846 Holocene of the Northern Chukotka. Moscow Univ Geol Bull. 2018;73:87-99.

65. Vasil'chuk YK, Vasil'chuk AC. Ice wedges in the Mayn River Valley and winter air paleotemperatures in the Souther Chukchi Peninsula at 38-12 kyr BP. Earth's Cryosph. 2017;21:24-35.

67. Mackay JR. Offshore permafrost and ground ice, southern Beaufort Sea. Can J Earth Sci. 1972;9:1550-1561.

68. Michel FA, Fritz P. Significance of isotope variations in permafrost waters at Illisarvik, 856 N.W.T. Proc 4th Can Permafr Conf. 1982:173-181.

69. Fritz M, Wetterich S, Schirrmeister L, et al. Eastern Beringia and beyond: Late Wisconsinan and Holocene landscape dynamics along the Yukon Coastal Plain, Canada. Palaeogeogr Palaeoclimatol Palaeoecol. 2012;319-320:28-45.

860 70. Michel FA. Isotopic composition of ice-wedge ice in northwestern Canada. Proc 5th $861 \quad$ Can Permafr Conf. 1990:5-9. 
862 71. Steffensen JP, Andersen KK, Bigler M, et al. High-resolution Greenland ice core data 863 show abrupt climate change happens in few years. Science. 2008;321:680-684.

864 72. lizuka Y, Miyamoto C, Matoba S, et al. Ion concentrations in ice wedges: An 865 innovative approach to reconstruct past climate variability. Earth Planet Sci Lett. $866 \quad 2019 ; 515: 58-66$.

867 73. Praetorius SK, Mix AC. Synchronization of North Pacific and Greenland climates $868 \quad$ preceded abrupt deglacial warming. Science. 2014;345:444-448.

869 74. Lachniet MS, Lawson DE, Stephen H, Sloat AR, Patterson WP. Isoscapes of $\delta 180$ 870 and $\mathrm{\delta} 2 \mathrm{H}$ reveal climatic forcings on Alaska and Yukon precipitation. Water Resour 871 Res. 2016;52:6575-6586.

872 75. Meyer H, Yoshikawa K, Schirrmeister L, Andreev A. The Vault Creek Tunnel 873 (Fairbanks region, Alaska); a late Quaternary palaeoenvironmental permafrost record. 874 9th Int Conf Permafr Proc. 2008:1191-1196.

875 76. Lacelle D, St-Jean M, Lauriol B, et al. Burial and preservation of a 30,000 year old 876 perennial snowbank in Red Creek valley, Ogilvie Mountains, central Yukon, Canada. 877 Quat Sci Rev. 2009;28(27-28):3401-3413. 


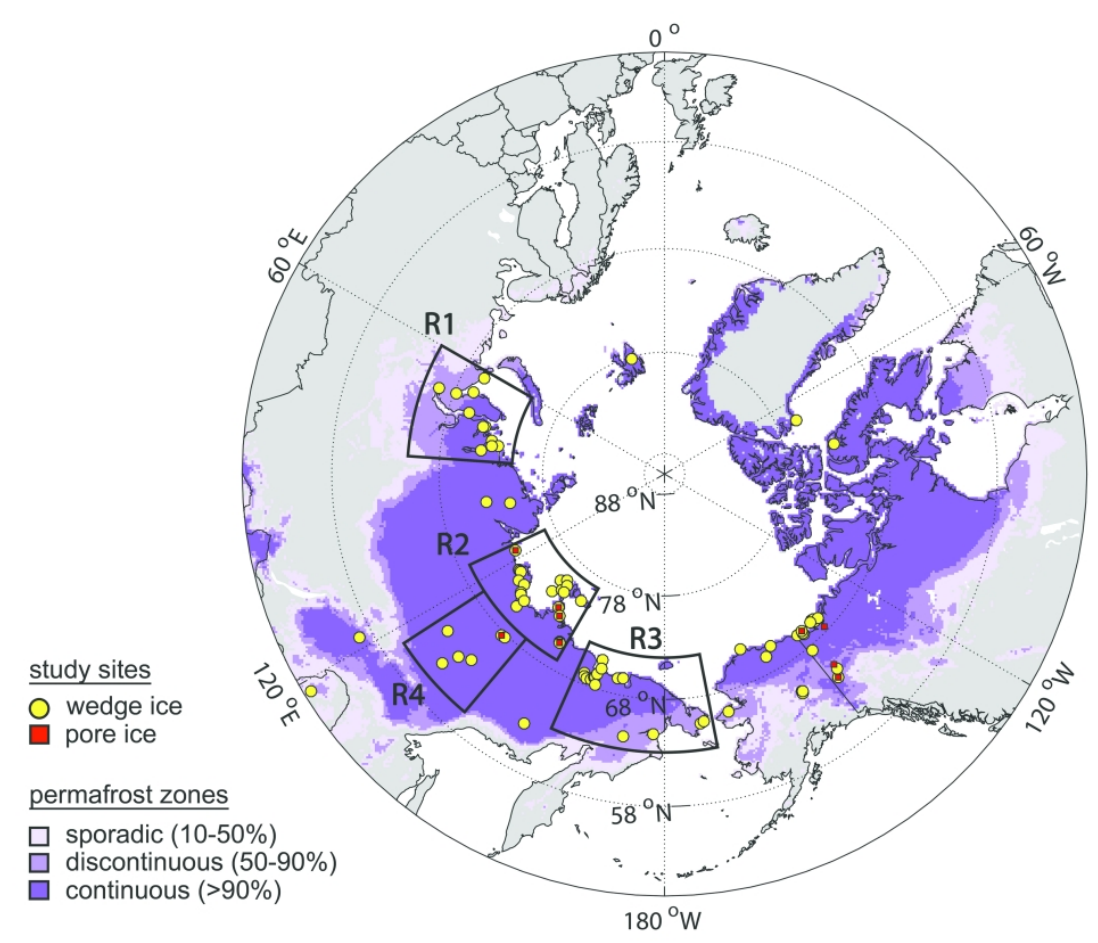

Figure 1. Sites of recent studies of water isotopes in relict wedge ice (yellow circles) and pore ice (red squares); Russian sub-regions of W. Siberia (R1), Laptev Sea region (R2), Kolyma and Chukotka (R3) and central Yakutia (R4) are indicated; modelled permafrost zones ${ }^{24}$ are indicated.

$320 \times 254 \mathrm{~mm}(300 \times 300 \mathrm{DPI})$ 

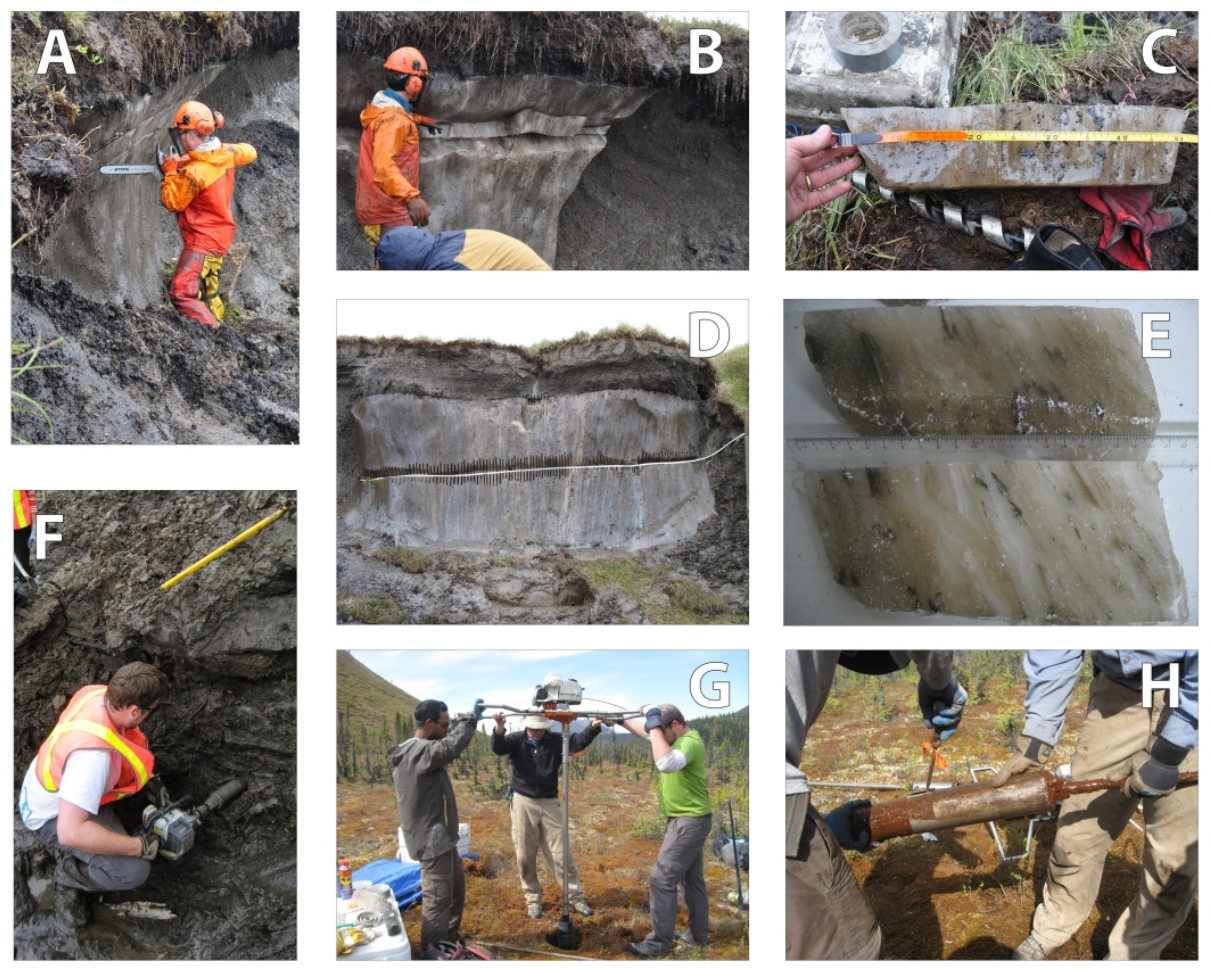

Figure 2. Ice-wedge and pore-ice sampling. (A) Ice-wedge sampling by chainsaw; $(B, C)$ block cuts from an ice wedge; (D) slice cut from an ice wedge; $(E)$ internal foliation of an ice wedge with visible ice veins and sediment and organic inclusions; (F) pore-ice sampling by lateral coring of a permafrost exposure using a hand-held drill; $(G)$ pore-ice sampling by vertical coring into permafrost using a gas-powered drill; and $(H)$ recovering the permafrost core from the 'core catcher'.

$544 \times 449 \mathrm{~mm}(300 \times 300 \mathrm{DPI})$ 
(a)

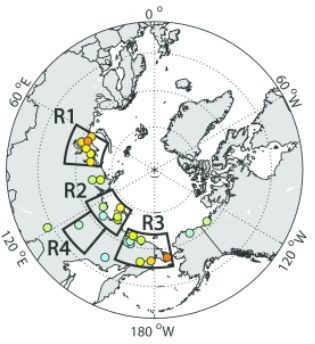

(c)

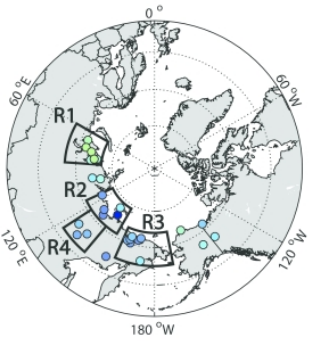

(b)

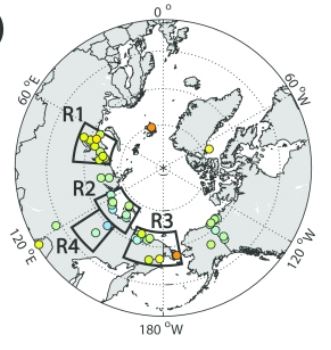

(d)

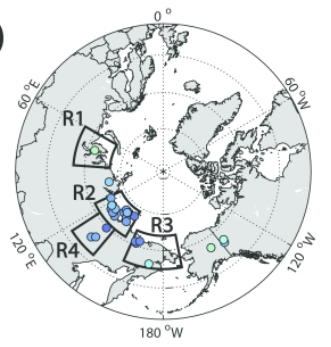

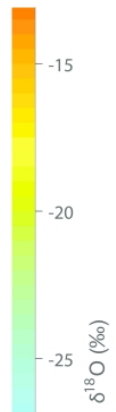

Figure 3. Average wedge-ice $\delta^{18} \mathrm{O}$ values dating to (a) modern, (b) Holocene, (c) MIS 2 and (d) MIS 3 from studies since 2010 (see Table S1 for data and sources); Russian sub-regions of W. Siberia (R1), Laptev Sea region (R2), Kolyma and Chukotka (R3) and central Yakutia (R4) are indicated.

$382 \times 254 \mathrm{~mm}(500 \times 500 \mathrm{DPI})$ 


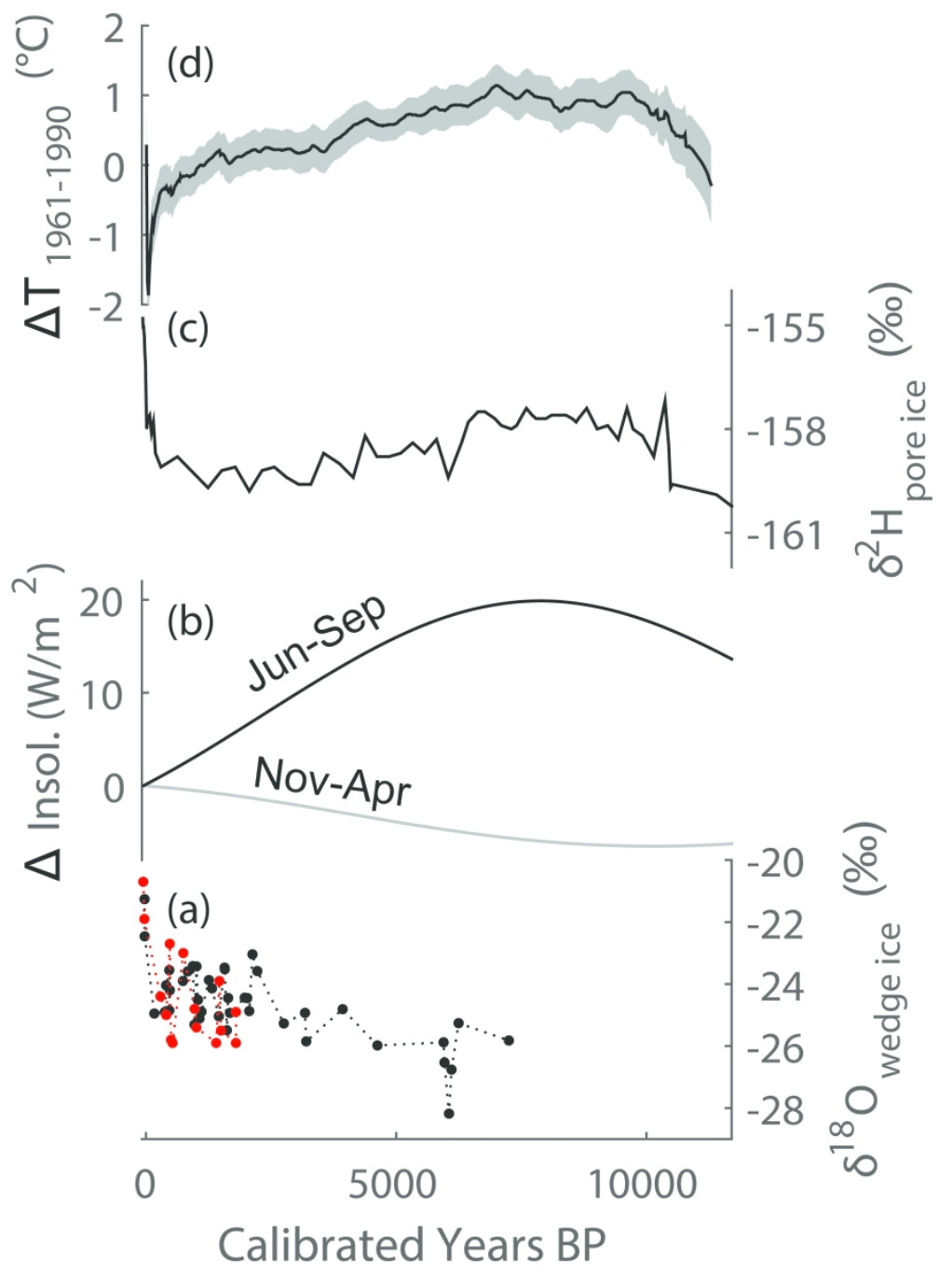

Figure 4. Holocene paleoclimate reconstructions and relict ground-ice water-isotope records. (a) Multi-site stacked wedge-ice $\delta^{18} \mathrm{O}$ record from the Lena Delta ${ }^{8}$ (black dashed line) and a single-site stacked wedge-ice $\delta^{18} \mathrm{O}$ record from the Oyogos Yar coast ${ }^{50}$ (red dashed line); (b) insolation change relative to modern during the warm-season (Jun-Sep) and cold-season (Nov-Apr) after Laskar et al. ${ }^{58}$; (c) pore-ice $\delta^{2} \mathrm{H}$ record from DHP174 site in central Yukon ${ }^{13}$; (d) Northern Hemisphere multi-proxy temperature reconstruction ${ }^{59}$.

$123 \times 167 \mathrm{~mm}(500 \times 500$ DPI $)$ 

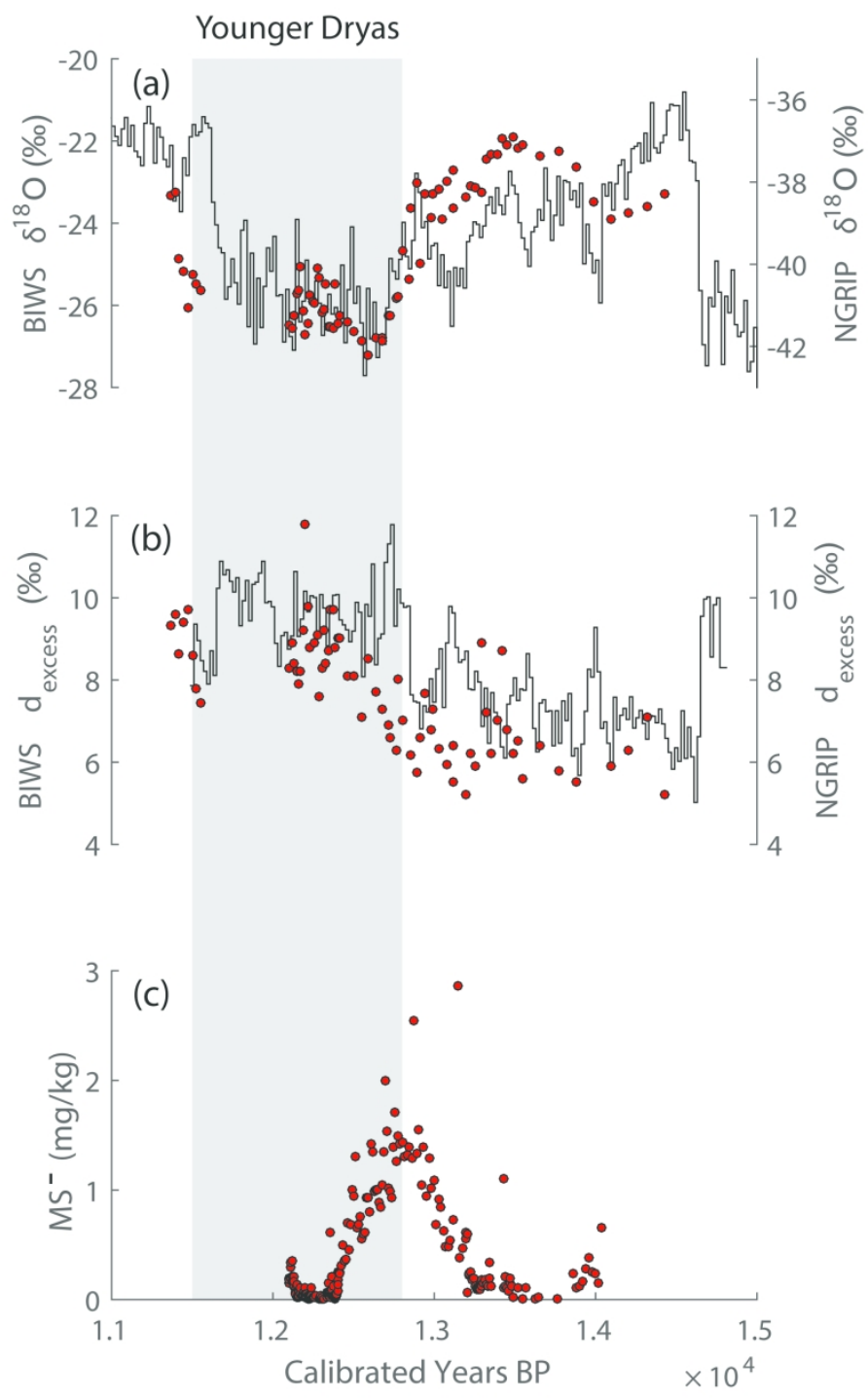

Figure 5. Water isotope and phytoplankton-derived methanesulfonate ion (MS-) records dating to the Younger Dryas transition from the Barrow Ice Wedge System (BIWS) and NGRIP ice core. $(a, b) \delta^{18} O$ and $\mathrm{d}_{\text {excess }}$ records from BIWS ${ }^{18}$ (red circles) and NGRIP ${ }^{71}$ (black line). (c) MS- ion concentration from BIWS ${ }^{72}$ (red circles).

$165 \times 254 \mathrm{~mm}(300 \times 300 \mathrm{DPI})$ 


\begin{tabular}{|c|c|c|c|c|}
\hline Site ID & Country & Site name & Latitude & Longitude \\
\hline 1 & Russia & Amderma & 70.00 & 62.00 \\
\hline 2 & Russia & Marre-Sale Cape & 69.68 & 66.80 \\
\hline 3 & Russia & Erkutayakha River & 68.19 & 68.86 \\
\hline 4 & Russia & Shchuchya River & 66.50 & 69.00 \\
\hline 5 & Russia & Seyakha Vostochnaya River & 70.00 & 72.50 \\
\hline 6 & Russia & Gydan Peninsula & 71.80 & 75.20 \\
\hline 7 & Russia & Era-Maretayakha & 71.65 & 75.42 \\
\hline 8 & Russia & Sibiryakov Island & 72.72 & 79.10 \\
\hline 9 & Russia & Dikson & 73.52 & 80.57 \\
\hline 10 & Russia & Krestyanka River & 72.90 & 80.90 \\
\hline 11 & Russia & Sopochnaya Karga Cape & 71.90 & 82.60 \\
\hline 12 & Russia & Labaz Lake & 72.33 & 99.00 \\
\hline 13 & Russia & Cape Sabler & 74.55 & 100.53 \\
\hline 14 & Russia & Mamontov Klyk & 73.60 & 117.17 \\
\hline 15 & Russia & Chara River & 56.77 & 118.10 \\
\hline 16 & Russia & Nagym, Lena Delta & 72.90 & 123.20 \\
\hline 17 & Russia & Turakh, Lena Delta & 72.97 & 123.80 \\
\hline 18 & Russia & Khardang, Lena Delta & 73.00 & 124.20 \\
\hline 19 & Russia & Vilyui near Tyalychima River & 64.00 & 126.00 \\
\hline 20 & Russia & Central Lena Delta & 72.38 & 126.12 \\
\hline 21 & Russia & Kurungnakh, Lena Delta & 72.30 & 126.30 \\
\hline 22 & Russia & Sobo Sise, Lena Delta & 72.50 & 128.30 \\
\hline 23 & Russia & Bykovsky Peninsula & 71.78 & 129.43 \\
\hline 24 & Russia & Muostakh Island & 71.60 & 130.00 \\
\hline 25 & Russia & Cyuie & 61.73 & 130.42 \\
\hline 26 & Russia & Tanda & 63.30 & 131.70 \\
\hline 27 & Russia & Kular & 70.63 & 131.88 \\
\hline 28 & Russia & Buor Khaya & 71.50 & 132.10 \\
\hline 29 & Russia & Mamontova Gora & 64.00 & 134.00 \\
\hline 30 & Russia & Batagay & 67.60 & 134.80 \\
\hline 31 & Russia & Adycha & 67.66 & 135.69 \\
\hline 32 & Russia & Belkovsky Island & 75.40 & 135.60 \\
\hline 33 & Russia & Stolbovoy Island & 74.10 & 136.10 \\
\hline 34 & Russia & Kotelny Island, north coast & 75.80 & 137.50 \\
\hline 35 & Russia & Kotelny Island & 74.70 & 138.50 \\
\hline 36 & Russia & Kotelny Island, Balyktakh river & 75.43 & 138.82 \\
\hline 37 & Russia & Kotelny Island, south coast & 74.80 & 139.60 \\
\hline 38 & Russia & Bol'shoy Lyakhovsky & 73.30 & 141.50 \\
\hline 39 & Russia & Oyogos Yar & 72.70 & 143.50 \\
\hline 40 & Russia & Novaya Sibir' Island & 75.10 & 146.70 \\
\hline 41 & Russia & Boydom & 70.64 & 148.15 \\
\hline 42 & Russia & Kryvaya & 70.56 & 148.26 \\
\hline 43 & Russia & Pit Phoenix & 62.25 & 150.75 \\
\hline 44 & Russia & Bison, Kolyma River basin & 69.00 & 158.00 \\
\hline 45 & Russia & Alyoshkinskaya terrace & 68.72 & 158.40 \\
\hline 46 & Russia & Duvanny Yar & 68.63 & 159.15 \\
\hline 47 & Russia & Plakhinskii Yar & 68.68 & 160.29 \\
\hline 48 & Russia & Zelyony Mys & 69.00 & 161.00 \\
\hline 49 & Russia & Pokhodsk & 69.04 & 161.01 \\
\hline 50 & Russia & Stanchikovsky Yar & 69.37 & 161.52 \\
\hline
\end{tabular}




\begin{tabular}{|c|c|c|c|c|}
\hline 51 & Russia & Chetyrekhstolbovy Island & 70.78 & 161.60 \\
\hline 52 & Russia & Krasivoe & 68.30 & 161.73 \\
\hline 53 & Russia & Ambarchik Polar Station & 70.00 & 162.00 \\
\hline 54 & Russia & Rauchua River & 69.50 & 167.00 \\
\hline 55 & Russia & Ayon Island & 69.63 & 168.58 \\
\hline 56 & Russia & Mayn River Valley & 64.17 & 171.04 \\
\hline 57 & Russia & Anadyr Town & 64.73 & 177.52 \\
\hline 58 & Russia & Lorino Settlement & 65.50 & -171.72 \\
\hline 59 & Russia & Lavrentiya Settlement & 65.58 & -170.99 \\
\hline 60 & Norway & Adventdalen & 78.20 & 15.83 \\
\hline 61 & Denmark & Annikitisoq & 76.03 & -67.62 \\
\hline 62 & China & Yitulihe & 50.62 & 121.53 \\
\hline 63 & USA & Northern Seward Peninsula & 66.00 & -165.00 \\
\hline 64 & USA & Barrow & 71.30 & -156.67 \\
\hline 65 & USA & Itkilik & 69.57 & -150.87 \\
\hline 66 & USA & Prudhoe Bay & 70.20 & -148.40 \\
\hline 67 & USA & Vault Creek Tunnel, Chatanika River & 65.03 & -147.70 \\
\hline 68 & USA & Fairbanks & 64.80 & -147.70 \\
\hline 69 & USA & CRREL Fox Tunnel & 64.95 & -147.62 \\
\hline 70 & Canada & Komakuk Beach & 69.60 & -140.50 \\
\hline 71 & Canada & Old Crow & 67.58 & -140.00 \\
\hline 72 & Canada & Klondike & 64.06 & -139.41 \\
\hline 73 & Canada & Kay Point & 69.25 & -139.19 \\
\hline 74 & Canada & Roland Bay & 69.43 & -139.00 \\
\hline 75 & Canada & Herschel Island & 69.60 & -138.96 \\
\hline 76 & Canada & Moose Lake & 64.74 & -138.37 \\
\hline 77 & Canada & DHP174 & 65.21 & -138.32 \\
\hline 78 & Canada & Illisarvik & 69.48 & -134.59 \\
\hline 79 & Canada & Inuvik & 68.39 & -133.76 \\
\hline 80 & Canada & Hooper Island & 69.69 & -134.85 \\
\hline 81 & Canada & Richards Island, North Point & 69.70 & -134.24 \\
\hline 82 & Canada & Pingo Canadian Landmark area & 69.41 & -133.12 \\
\hline 83 & Canada & Pelly Island & 69.63 & -135.43 \\
\hline 84 & Canada & Bylot Island & 73.16 & -79.94 \\
\hline
\end{tabular}




\begin{tabular}{|c|c|c|c|c|c|c|}
\hline \multirow[b]{2}{*}{ Wedge ice } & \multirow[b]{2}{*}{ Pore ice } & \multicolumn{3}{|c|}{ ca. modern } & \multicolumn{2}{|c|}{ Holocene } \\
\hline & & $\delta 180$ & s.d. & $\mathbf{n}$ & $\delta 180$ & s.d. \\
\hline$x$ & $\mathrm{n} / \mathrm{a}$ & -16.5 & $\mathrm{n} / \mathrm{a}$ & 4 & -20.9 & $\mathrm{n} / \mathrm{a}$ \\
\hline$x$ & $\mathrm{n} / \mathrm{a}$ & -14 & $\mathrm{n} / \mathrm{a}$ & 2 & -16.7 & $\mathrm{n} / \mathrm{a}$ \\
\hline$x$ & $\mathrm{n} / \mathrm{a}$ & $\mathrm{n} / \mathrm{a}$ & $\mathrm{n} / \mathrm{a}$ & $\mathrm{n} / \mathrm{a}$ & -19.6 & 0.7 \\
\hline$x$ & $\mathrm{n} / \mathrm{a}$ & $\mathrm{n} / \mathrm{a}$ & $\mathrm{n} / \mathrm{a}$ & $\mathrm{n} / \mathrm{a}$ & -19.4 & $\mathrm{n} / \mathrm{a}$ \\
\hline$x$ & $\mathrm{n} / \mathrm{a}$ & -17.3 & $\mathrm{n} / \mathrm{a}$ & 2 & -19.7 & $\mathrm{n} / \mathrm{a}$ \\
\hline$x$ & $\mathrm{n} / \mathrm{a}$ & -18.8 & $\mathrm{n} / \mathrm{a}$ & 3 & -21.9 & $\mathrm{n} / \mathrm{a}$ \\
\hline$x$ & $\mathrm{n} / \mathrm{a}$ & -19 & $\mathrm{n} / \mathrm{a}$ & $\mathrm{n} / \mathrm{a}$ & $\mathrm{n} / \mathrm{a}$ & $\mathrm{n} / \mathrm{a}$ \\
\hline$x$ & $\mathrm{n} / \mathrm{a}$ & $\mathrm{n} / \mathrm{a}$ & $\mathrm{n} / \mathrm{a}$ & $\mathrm{n} / \mathrm{a}$ & -19.9 & $\mathrm{n} / \mathrm{a}$ \\
\hline$x$ & $\mathrm{n} / \mathrm{a}$ & $\mathrm{n} / \mathrm{a}$ & $\mathrm{n} / \mathrm{a}$ & $\mathrm{n} / \mathrm{a}$ & -20.7 & $\mathrm{n} / \mathrm{a}$ \\
\hline$x$ & $\mathrm{n} / \mathrm{a}$ & $\mathrm{n} / \mathrm{a}$ & $\mathrm{n} / \mathrm{a}$ & $\mathrm{n} / \mathrm{a}$ & $\mathrm{n} / \mathrm{a}$ & $\mathrm{n} / \mathrm{a}$ \\
\hline$x$ & $\mathrm{n} / \mathrm{a}$ & -16.6 & $\mathrm{n} / \mathrm{a}$ & 4 & -20.3 & $\mathrm{n} / \mathrm{a}$ \\
\hline$x$ & $\mathrm{n} / \mathrm{a}$ & -22 & $\mathrm{n} / \mathrm{a}$ & $\mathrm{n} / \mathrm{a}$ & -23 & $\mathrm{n} / \mathrm{a}$ \\
\hline$x$ & $\mathrm{n} / \mathrm{a}$ & -20.4 & $\mathrm{n} / \mathrm{a}$ & 5 & -23.1 & $\mathrm{n} / \mathrm{a}$ \\
\hline$x$ & $x$ & -20.5 & 1 & 5 & -24.6 & $\mathrm{n} / \mathrm{a}$ \\
\hline$x$ & $\mathrm{n} / \mathrm{a}$ & -21.6 & 1.2 & 2 & -22.6 & 2.2 \\
\hline$x$ & $\mathrm{n} / \mathrm{a}$ & $\mathrm{n} / \mathrm{a}$ & $\mathrm{n} / \mathrm{a}$ & $\mathrm{n} / \mathrm{a}$ & -22.7 & $\mathrm{n} / \mathrm{a}$ \\
\hline$x$ & $\mathrm{n} / \mathrm{a}$ & $\mathrm{n} / \mathrm{a}$ & $\mathrm{n} / \mathrm{a}$ & $\mathrm{n} / \mathrm{a}$ & -22.9 & $\mathrm{n} / \mathrm{a}$ \\
\hline$x$ & $\mathrm{n} / \mathrm{a}$ & $\mathrm{n} / \mathrm{a}$ & $\mathrm{n} / \mathrm{a}$ & $\mathrm{n} / \mathrm{a}$ & $\mathrm{n} / \mathrm{a}$ & $\mathrm{n} / \mathrm{a}$ \\
\hline$x$ & $\mathrm{n} / \mathrm{a}$ & -24.2 & $\mathrm{n} / \mathrm{a}$ & $\mathrm{n} / \mathrm{a}$ & $\mathrm{n} / \mathrm{a}$ & $\mathrm{n} / \mathrm{a}$ \\
\hline$x$ & $\mathrm{n} / \mathrm{a}$ & -22.2 & $\mathrm{n} / \mathrm{a}$ & 12 & -24.6 & 1.2 \\
\hline$x$ & $\mathrm{n} / \mathrm{a}$ & $\mathrm{n} / \mathrm{a}$ & $\mathrm{n} / \mathrm{a}$ & $\mathrm{n} / \mathrm{a}$ & $\mathrm{n} / \mathrm{a}$ & $\mathrm{n} / \mathrm{a}$ \\
\hline $\mathrm{x}$ & $\mathrm{n} / \mathrm{a}$ & $\mathrm{n} / \mathrm{a}$ & $\mathrm{n} / \mathrm{a}$ & $\mathrm{n} / \mathrm{a}$ & $\mathrm{n} / \mathrm{a}$ & $\mathrm{n} / \mathrm{a}$ \\
\hline$x$ & $\mathrm{n} / \mathrm{a}$ & $\mathrm{n} / \mathrm{a}$ & $\mathrm{n} / \mathrm{a}$ & $\mathrm{n} / \mathrm{a}$ & -28.2 & $\mathrm{n} / \mathrm{a}$ \\
\hline$x$ & $\mathrm{n} / \mathrm{a}$ & $\mathrm{n} / \mathrm{a}$ & $\mathrm{n} / \mathrm{a}$ & $\mathrm{n} / \mathrm{a}$ & $\mathrm{n} / \mathrm{a}$ & $\mathrm{n} / \mathrm{a}$ \\
\hline$x$ & $\mathrm{n} / \mathrm{a}$ & $\mathrm{n} / \mathrm{a}$ & $\mathrm{n} / \mathrm{a}$ & $\mathrm{n} / \mathrm{a}$ & $\mathrm{n} / \mathrm{a}$ & $\mathrm{n} / \mathrm{a}$ \\
\hline$x$ & $\mathrm{n} / \mathrm{a}$ & $\mathrm{n} / \mathrm{a}$ & $\mathrm{n} / \mathrm{a}$ & $\mathrm{n} / \mathrm{a}$ & $\mathrm{n} / \mathrm{a}$ & $\mathrm{n} / \mathrm{a}$ \\
\hline$x$ & $\mathrm{n} / \mathrm{a}$ & -26 & $\mathrm{n} / \mathrm{a}$ & $\mathrm{n} / \mathrm{a}$ & $\mathrm{n} / \mathrm{a}$ & $\mathrm{n} / \mathrm{a}$ \\
\hline$x$ & $\mathrm{n} / \mathrm{a}$ & $\mathrm{n} / \mathrm{a}$ & $\mathrm{n} / \mathrm{a}$ & $\mathrm{n} / \mathrm{a}$ & $\mathrm{n} / \mathrm{a}$ & $\mathrm{n} / \mathrm{a}$ \\
\hline$x$ & $\mathrm{n} / \mathrm{a}$ & $\mathrm{n} / \mathrm{a}$ & $\mathrm{n} / \mathrm{a}$ & $\mathrm{n} / \mathrm{a}$ & -24.2 & $\mathrm{n} / \mathrm{a}$ \\
\hline$x$ & $x$ & $\mathrm{n} / \mathrm{a}$ & $\mathrm{n} / \mathrm{a}$ & $\mathrm{n} / \mathrm{a}$ & $\mathrm{n} / \mathrm{a}$ & $\mathrm{n} / \mathrm{a}$ \\
\hline$x$ & $\mathrm{n} / \mathrm{a}$ & $\mathrm{n} / \mathrm{a}$ & $\mathrm{n} / \mathrm{a}$ & $\mathrm{n} / \mathrm{a}$ & -29 & 0.7 \\
\hline$x$ & $\mathrm{n} / \mathrm{a}$ & $\mathrm{n} / \mathrm{a}$ & $\mathrm{n} / \mathrm{a}$ & $\mathrm{n} / \mathrm{a}$ & $\mathrm{n} / \mathrm{a}$ & $\mathrm{n} / \mathrm{a}$ \\
\hline$x$ & $\mathrm{n} / \mathrm{a}$ & $\mathrm{n} / \mathrm{a}$ & $\mathrm{n} / \mathrm{a}$ & $\mathrm{n} / \mathrm{a}$ & $\mathrm{n} / \mathrm{a}$ & $\mathrm{n} / \mathrm{a}$ \\
\hline$x$ & $\mathrm{n} / \mathrm{a}$ & $\mathrm{n} / \mathrm{a}$ & $\mathrm{n} / \mathrm{a}$ & $\mathrm{n} / \mathrm{a}$ & -22.5 & 0.4 \\
\hline$x$ & $\mathrm{n} / \mathrm{a}$ & -18 & $\mathrm{n} / \mathrm{a}$ & $\mathrm{n} / \mathrm{a}$ & $\mathrm{n} / \mathrm{a}$ & $\mathrm{n} / \mathrm{a}$ \\
\hline$x$ & $\mathrm{n} / \mathrm{a}$ & $\mathrm{n} / \mathrm{a}$ & $\mathrm{n} / \mathrm{a}$ & $\mathrm{n} / \mathrm{a}$ & -25 & 1.2 \\
\hline$x$ & $\mathrm{n} / \mathrm{a}$ & $\mathrm{n} / \mathrm{a}$ & $\mathrm{n} / \mathrm{a}$ & $\mathrm{n} / \mathrm{a}$ & $\mathrm{n} / \mathrm{a}$ & $\mathrm{n} / \mathrm{a}$ \\
\hline$x$ & $x$ & -20.4 & 1.27 & 8 & -24.2 & 1.1 \\
\hline$x$ & $x$ & -20.7 & 1.61 & 11 & -25.1 & 1.1 \\
\hline$x$ & $\mathrm{n} / \mathrm{a}$ & $\mathrm{n} / \mathrm{a}$ & $\mathrm{n} / \mathrm{a}$ & $\mathrm{n} / \mathrm{a}$ & $\mathrm{n} / \mathrm{a}$ & $\mathrm{n} / \mathrm{a}$ \\
\hline$x$ & $x$ & $\mathrm{n} / \mathrm{a}$ & $\mathrm{n} / \mathrm{a}$ & $\mathrm{n} / \mathrm{a}$ & -28.3 & 1 \\
\hline$x$ & $x$ & $\mathrm{n} / \mathrm{a}$ & $\mathrm{n} / \mathrm{a}$ & $\mathrm{n} / \mathrm{a}$ & -26.1 & 0.4 \\
\hline$x$ & $\mathrm{n} / \mathrm{a}$ & -27 & $\mathrm{n} / \mathrm{a}$ & $\mathrm{n} / \mathrm{a}$ & $\mathrm{n} / \mathrm{a}$ & $\mathrm{n} / \mathrm{a}$ \\
\hline$x$ & $\mathrm{n} / \mathrm{a}$ & -25.3 & $\mathrm{n} / \mathrm{a}$ & 7 & -27 & $\mathrm{n} / \mathrm{a}$ \\
\hline$x$ & $\mathrm{n} / \mathrm{a}$ & -26 & $\mathrm{n} / \mathrm{a}$ & $\mathrm{n} / \mathrm{a}$ & $\mathrm{n} / \mathrm{a}$ & $\mathrm{n} / \mathrm{a}$ \\
\hline$x$ & $\mathrm{n} / \mathrm{a}$ & -25.1 & $\mathrm{n} / \mathrm{a}$ & $\mathrm{n} / \mathrm{a}$ & $\mathrm{n} / \mathrm{a}$ & $\mathrm{n} / \mathrm{a}$ \\
\hline$x$ & $\mathrm{n} / \mathrm{a}$ & -25.8 & $\mathrm{n} / \mathrm{a}$ & $\mathrm{n} / \mathrm{a}$ & -25.8 & 1.4 \\
\hline $\mathrm{x}$ & $\mathrm{n} / \mathrm{a}$ & -25.5 & $\mathrm{n} / \mathrm{a}$ & $\mathrm{n} / \mathrm{a}$ & $\mathrm{n} / \mathrm{a}$ & $\mathrm{n} / \mathrm{a}$ \\
\hline $\mathrm{x}$ & $\mathrm{n} / \mathrm{a}$ & $\mathrm{n} / \mathrm{a}$ & $\mathrm{n} / \mathrm{a}$ & $\mathrm{n} / \mathrm{a}$ & -26.6 & 0.6 \\
\hline$x$ & $\mathrm{n} / \mathrm{a}$ & $\mathrm{n} / \mathrm{a}$ & $\mathrm{n} / \mathrm{a}$ & $\mathrm{n} / \mathrm{a}$ & $\mathrm{n} / \mathrm{a}$ & $\mathrm{n} / \mathrm{a}$ \\
\hline
\end{tabular}




\begin{tabular}{|c|c|c|c|c|c|c|}
\hline$x$ & $\mathrm{n} / \mathrm{a}$ & -19.2 & $\mathrm{n} / \mathrm{a}$ & 14 & -20.3 & $\mathrm{n} / \mathrm{a}$ \\
\hline$x$ & $\mathrm{n} / \mathrm{a}$ & -26 & $\mathrm{n} / \mathrm{a}$ & $\mathrm{n} / \mathrm{a}$ & $\mathrm{n} / \mathrm{a}$ & $\mathrm{n} / \mathrm{a}$ \\
\hline$x$ & $\mathrm{n} / \mathrm{a}$ & $\mathrm{n} / \mathrm{a}$ & $\mathrm{n} / \mathrm{a}$ & $\mathrm{n} / \mathrm{a}$ & $\mathrm{n} / \mathrm{a}$ & $\mathrm{n} / \mathrm{a}$ \\
\hline$x$ & $\mathrm{n} / \mathrm{a}$ & $\mathrm{n} / \mathrm{a}$ & $\mathrm{n} / \mathrm{a}$ & $\mathrm{n} / \mathrm{a}$ & -23 & $\mathrm{n} / \mathrm{a}$ \\
\hline$x$ & $\mathrm{n} / \mathrm{a}$ & -20 & $\mathrm{n} / \mathrm{a}$ & $\mathrm{n} / \mathrm{a}$ & -21.6 & 0.5 \\
\hline$x$ & $n / a$ & -20 & $n / a$ & $\mathrm{n} / \mathrm{a}$ & -20.2 & 0.2 \\
\hline$x$ & $\mathrm{n} / \mathrm{a}$ & -16.1 & $\mathrm{n} / \mathrm{a}$ & 2 & -18.45 & $\mathrm{n} / \mathrm{a}$ \\
\hline$x$ & $\mathrm{n} / \mathrm{a}$ & -13.1 & $\mathrm{n} / \mathrm{a}$ & 4 & -16.5 & $\mathrm{n} / \mathrm{a}$ \\
\hline$x$ & $\mathrm{n} / \mathrm{a}$ & $\mathrm{n} / \mathrm{a}$ & $\mathrm{n} / \mathrm{a}$ & $\mathrm{n} / \mathrm{a}$ & -14 & $\mathrm{n} / \mathrm{a}$ \\
\hline$x$ & $\mathrm{n} / \mathrm{a}$ & $\mathrm{n} / \mathrm{a}$ & $\mathrm{n} / \mathrm{a}$ & $\mathrm{n} / \mathrm{a}$ & -13.9 & 0.7 \\
\hline$x$ & $\mathrm{n} / \mathrm{a}$ & $\mathrm{n} / \mathrm{a}$ & $\mathrm{n} / \mathrm{a}$ & $\mathrm{n} / \mathrm{a}$ & -18 & 0.8 \\
\hline$x$ & $\mathrm{n} / \mathrm{a}$ & $\mathrm{n} / \mathrm{a}$ & $\mathrm{n} / \mathrm{a}$ & $\mathrm{n} / \mathrm{a}$ & -18.8 & $\mathrm{n} / \mathrm{a}$ \\
\hline$x$ & $\mathrm{n} / \mathrm{a}$ & $\mathrm{n} / \mathrm{a}$ & $\mathrm{n} / \mathrm{a}$ & $\mathrm{n} / \mathrm{a}$ & -17.3 & $\mathrm{n} / \mathrm{a}$ \\
\hline$x$ & $\mathrm{n} / \mathrm{a}$ & $\mathrm{n} / \mathrm{a}$ & $\mathrm{n} / \mathrm{a}$ & $\mathrm{n} / \mathrm{a}$ & -21.5 & 1.4 \\
\hline$x$ & $\mathrm{n} / \mathrm{a}$ & -25 & $\mathrm{n} / \mathrm{a}$ & 3 & $\mathrm{n} / \mathrm{a}$ & $\mathrm{n} / \mathrm{a}$ \\
\hline$x$ & $\mathrm{n} / \mathrm{a}$ & $\mathrm{n} / \mathrm{a}$ & $\mathrm{n} / \mathrm{a}$ & $\mathrm{n} / \mathrm{a}$ & -23.67 & 1.5 \\
\hline$x$ & $\mathrm{n} / \mathrm{a}$ & $\mathrm{n} / \mathrm{a}$ & $\mathrm{n} / \mathrm{a}$ & $\mathrm{n} / \mathrm{a}$ & -21.9 & $\mathrm{n} / \mathrm{a}$ \\
\hline$x$ & $n / a$ & $\mathrm{n} / \mathrm{a}$ & $\mathrm{n} / \mathrm{a}$ & $\mathrm{n} / \mathrm{a}$ & $\mathrm{n} / \mathrm{a}$ & $\mathrm{n} / \mathrm{a}$ \\
\hline$x$ & $n / a$ & $\mathrm{n} / \mathrm{a}$ & $\mathrm{n} / \mathrm{a}$ & $\mathrm{n} / \mathrm{a}$ & $\mathrm{n} / \mathrm{a}$ & $\mathrm{n} / \mathrm{a}$ \\
\hline$x$ & $\mathrm{n} / \mathrm{a}$ & $\mathrm{n} / \mathrm{a}$ & $n / a$ & $\mathrm{n} / \mathrm{a}$ & -23.3 & $\mathrm{n} / \mathrm{a}$ \\
\hline$x$ & $\mathrm{n} / \mathrm{a}$ & $n / a$ & $\mathrm{n} / \mathrm{a}$ & $\mathrm{n} / \mathrm{a}$ & -25 & 1 \\
\hline$x$ & $x$ & $\mathrm{n} / \mathrm{a}$ & $\mathrm{n} / \mathrm{a}$ & $\mathrm{n} / \mathrm{a}$ & -24.5 & 0.5 \\
\hline$x$ & $\mathrm{n} / \mathrm{a}$ & $\mathrm{n} / \mathrm{a}$ & $n / a$ & $\mathrm{n} / \mathrm{a}$ & -19.14 & 0.6 \\
\hline$x$ & $\mathrm{n} / \mathrm{a}$ & $\mathrm{n} / \mathrm{a}$ & $n / a$ & $\mathrm{n} / \mathrm{a}$ & -22.77 & 1.1 \\
\hline$x$ & $x$ & $\mathrm{n} / \mathrm{a}$ & $n / a$ & $\mathrm{n} / \mathrm{a}$ & -22.1 & $\mathrm{n} / \mathrm{a}$ \\
\hline$x$ & $\mathrm{n} / \mathrm{a}$ & $\mathrm{n} / \mathrm{a}$ & $n / a$ & $\mathrm{n} / \mathrm{a}$ & -23.9 & 0.5 \\
\hline $\mathrm{n} / \mathrm{a}$ & $x$ & $\mathrm{n} / \mathrm{a}$ & $n / a$ & $\mathrm{n} / \mathrm{a}$ & $\mathrm{n} / \mathrm{a}$ & $\mathrm{n} / \mathrm{a}$ \\
\hline$x$ & $\mathrm{n} / \mathrm{a}$ & -22.5 & $n / a$ & 1 & $\mathrm{n} / \mathrm{a}$ & $\mathrm{n} / \mathrm{a}$ \\
\hline $\mathrm{n} / \mathrm{a}$ & $x$ & $\mathrm{n} / \mathrm{a}$ & $\mathrm{n} / \mathrm{a}$ & $\mathrm{n} / \mathrm{a}$ & $\mathrm{n} / \mathrm{a}$ & $\mathrm{n} / \mathrm{a}$ \\
\hline$x$ & $\mathrm{n} / \mathrm{a}$ & $n / a$ & $\mathrm{n} / \mathrm{a}$ & $\mathrm{n} / \mathrm{a}$ & -23 & 0.7 \\
\hline$x$ & $\mathrm{n} / \mathrm{a}$ & $\mathrm{n} / \mathrm{a}$ & $\mathrm{n} / \mathrm{a}$ & $\mathrm{n} / \mathrm{a}$ & -24.6 & 0.8 \\
\hline$x$ & $\mathrm{n} / \mathrm{a}$ & $\mathrm{n} / \mathrm{a}$ & $\mathrm{n} / \mathrm{a}$ & $\mathrm{n} / \mathrm{a}$ & -24 & 0.6 \\
\hline$x$ & $\mathrm{n} / \mathrm{a}$ & $\mathrm{n} / \mathrm{a}$ & $\mathrm{n} / \mathrm{a}$ & $\mathrm{n} / \mathrm{a}$ & -25.2 & 0.4 \\
\hline$x$ & $\mathrm{n} / \mathrm{a}$ & $\mathrm{n} / \mathrm{a}$ & $\mathrm{n} / \mathrm{a}$ & $\mathrm{n} / \mathrm{a}$ & -25.63 & 0.95 \\
\hline
\end{tabular}




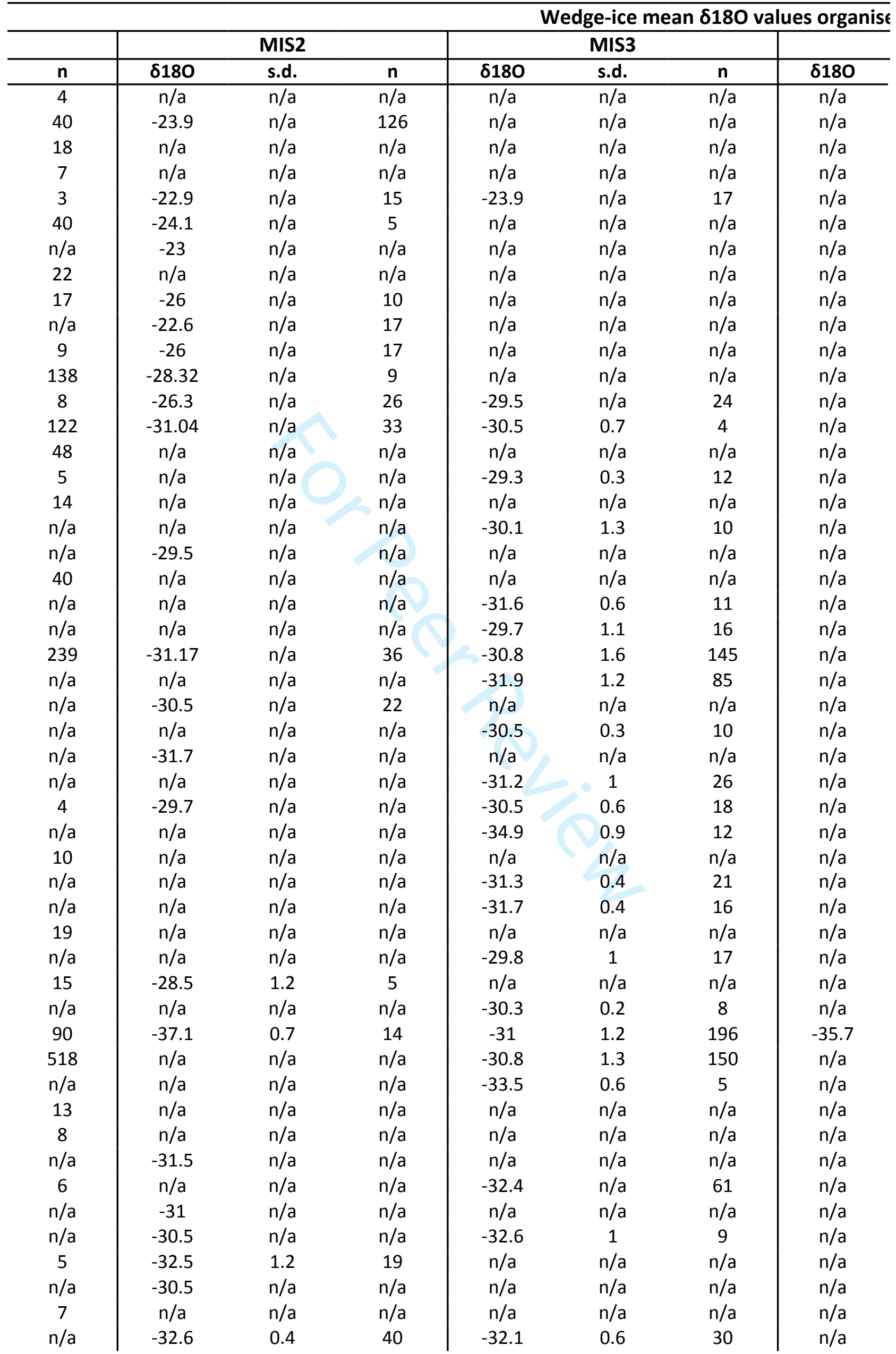




\begin{tabular}{|c|c|c|c|c|c|c|c|c|}
\hline $\begin{array}{l}1 \\
2\end{array}$ & 3 & $\mathrm{n} / \mathrm{a}$ & $\mathrm{n} / \mathrm{a}$ & $\mathrm{n} / \mathrm{a}$ & $\mathrm{n} / \mathrm{a}$ & $\mathrm{n} / \mathrm{a}$ & $\mathrm{n} / \mathrm{a}$ & $\mathrm{n} / \mathrm{a}$ \\
\hline 3 & $\mathrm{n} / \mathrm{a}$ & -31 & $\mathrm{n} / \mathrm{a}$ & $\mathrm{n} / \mathrm{a}$ & $\mathrm{n} / \mathrm{a}$ & $\mathrm{n} / \mathrm{a}$ & $\mathrm{n} / \mathrm{a}$ & $\mathrm{n} / \mathrm{a}$ \\
\hline 4 & $\mathrm{n} / \mathrm{a}$ & -29.2 & $\mathrm{n} / \mathrm{a}$ & 5 & $\mathrm{n} / \mathrm{a}$ & $\mathrm{n} / \mathrm{a}$ & $\mathrm{n} / \mathrm{a}$ & $\mathrm{n} / \mathrm{a}$ \\
\hline 5 & 3 & -31.2 & $\mathrm{n} / \mathrm{a}$ & 10 & $\mathrm{n} / \mathrm{a}$ & $\mathrm{n} / \mathrm{a}$ & $\mathrm{n} / \mathrm{a}$ & $\mathrm{n} / \mathrm{a}$ \\
\hline 6 & 8 & -30.4 & 1.1 & 60 & $\mathrm{n} / \mathrm{a}$ & $\mathrm{n} / \mathrm{a}$ & $\mathrm{n} / \mathrm{a}$ & $\mathrm{n} / \mathrm{a}$ \\
\hline $\begin{array}{l}7 \\
8\end{array}$ & 2 & -28 & 0.7 & 10 & -27.2 & 0.8 & 12 & $\mathrm{n} / \mathrm{a}$ \\
\hline $\begin{array}{l}8 \\
9\end{array}$ & 21 & $\mathrm{n} / \mathrm{a}$ & $\mathrm{n} / \mathrm{a}$ & $\mathrm{n} / \mathrm{a}$ & $\mathrm{n} / \mathrm{a}$ & $\mathrm{n} / \mathrm{a}$ & $\mathrm{n} / \mathrm{a}$ & $\mathrm{n} / \mathrm{a}$ \\
\hline 10 & 62 & $\mathrm{n} / \mathrm{a}$ & $\mathrm{n} / \mathrm{a}$ & $\mathrm{n} / \mathrm{a}$ & $\mathrm{n} / \mathrm{a}$ & $\mathrm{n} / \mathrm{a}$ & $\mathrm{n} / \mathrm{a}$ & $\mathrm{n} / \mathrm{a}$ \\
\hline 11 & 30 & $\mathrm{n} / \mathrm{a}$ & $\mathrm{n} / \mathrm{a}$ & $\mathrm{n} / \mathrm{a}$ & $\mathrm{n} / \mathrm{a}$ & $\mathrm{n} / \mathrm{a}$ & $\mathrm{n} / \mathrm{a}$ & $\mathrm{n} / \mathrm{a}$ \\
\hline 12 & 65 & $\mathrm{n} / \mathrm{a}$ & $\mathrm{n} / \mathrm{a}$ & $\mathrm{n} / \mathrm{a}$ & $\mathrm{n} / \mathrm{a}$ & $\mathrm{n} / \mathrm{a}$ & $\mathrm{n} / \mathrm{a}$ & $\mathrm{n} / \mathrm{a}$ \\
\hline 13 & 30 & $\mathrm{n} / \mathrm{a}$ & $\mathrm{n} / \mathrm{a}$ & $\mathrm{n} / \mathrm{a}$ & $\mathrm{n} / \mathrm{a}$ & $\mathrm{n} / \mathrm{a}$ & $\mathrm{n} / \mathrm{a}$ & $\mathrm{n} / \mathrm{a}$ \\
\hline 14 & 16 & $\mathrm{n} / \mathrm{a}$ & $\mathrm{n} / \mathrm{a}$ & $\mathrm{n} / \mathrm{a}$ & $\mathrm{n} / \mathrm{a}$ & $\mathrm{n} / \mathrm{a}$ & $\mathrm{n} / \mathrm{a}$ & $\mathrm{n} / \mathrm{a}$ \\
\hline $\begin{array}{l}15 \\
16\end{array}$ & $\mathrm{n} / \mathrm{a}$ & -24.3 & $\mathrm{n} / \mathrm{a}$ & $\mathrm{n} / \mathrm{a}$ & $\mathrm{n} / \mathrm{a}$ & $\mathrm{n} / \mathrm{a}$ & $\mathrm{n} / \mathrm{a}$ & $\mathrm{n} / \mathrm{a}$ \\
\hline $\begin{array}{l}16 \\
17\end{array}$ & 14 & -24.4 & 1.8 & 121 & $\mathrm{n} / \mathrm{a}$ & $\mathrm{n} / \mathrm{a}$ & $\mathrm{n} / \mathrm{a}$ & $\mathrm{n} / \mathrm{a}$ \\
\hline 18 & $\mathrm{n} / \mathrm{a}$ & $\mathrm{n} / \mathrm{a}$ & $\mathrm{n} / \mathrm{a}$ & $\mathrm{n} / \mathrm{a}$ & $\mathrm{n} / \mathrm{a}$ & $\mathrm{n} / \mathrm{a}$ & $\mathrm{n} / \mathrm{a}$ & $\mathrm{n} / \mathrm{a}$ \\
\hline 19 & 22 & $\mathrm{n} / \mathrm{a}$ & $\mathrm{n} / \mathrm{a}$ & $\mathrm{n} / \mathrm{a}$ & $\mathrm{n} / \mathrm{a}$ & $\mathrm{n} / \mathrm{a}$ & $\mathrm{n} / \mathrm{a}$ & $\mathrm{n} / \mathrm{a}$ \\
\hline 20 & $\mathrm{n} / \mathrm{a}$ & $\mathrm{n} / \mathrm{a}$ & $\mathrm{n} / \mathrm{a}$ & $\mathrm{n} / \mathrm{a}$ & $\mathrm{n} / \mathrm{a}$ & $\mathrm{n} / \mathrm{a}$ & $\mathrm{n} / \mathrm{a}$ & $\mathrm{n} / \mathrm{a}$ \\
\hline 21 & $\mathrm{n} / \mathrm{a}$ & -26.9 & $\mathrm{n} / \mathrm{a}$ & $\mathrm{n} / \mathrm{a}$ & $\mathrm{n} / \mathrm{a}$ & $\mathrm{n} / \mathrm{a}$ & $\mathrm{n} / \mathrm{a}$ & $\mathrm{n} / \mathrm{a}$ \\
\hline 22 & $\mathrm{n} / \mathrm{a}$ & -27.2 & $\mathrm{n} / \mathrm{a}$ & $\mathrm{n} / \mathrm{a}$ & $\mathrm{n} / \mathrm{a}$ & $\mathrm{n} / \mathrm{a}$ & $\mathrm{n} / \mathrm{a}$ & $\mathrm{n} / \mathrm{a}$ \\
\hline 23 & 25 & $\mathrm{n} / \mathrm{a}$ & $\mathrm{n} / \mathrm{a}$ & $\mathrm{n} / \mathrm{a}$ & $\mathrm{n} / \mathrm{a}$ & $\mathrm{n} / \mathrm{a}$ & $\mathrm{n} / \mathrm{a}$ & $\mathrm{n} / \mathrm{a}$ \\
\hline $\begin{array}{l}24 \\
25\end{array}$ & 46 & $\mathrm{n} / \mathrm{a}$ & $\mathrm{n} / \mathrm{a}$ & $\mathrm{n} / \mathrm{a}$ & $\mathrm{n} / \mathrm{a}$ & $\mathrm{n} / \mathrm{a}$ & $\mathrm{n} / \mathrm{a}$ & $\mathrm{n} / \mathrm{a}$ \\
\hline 26 & 3 & $\mathrm{n} / \mathrm{a}$ & $\mathrm{n} / \mathrm{a}$ & $\mathrm{n} / \mathrm{a}$ & -29.3 & 0.6 & 3 & $\mathrm{n} / \mathrm{a}$ \\
\hline 27 & 2 & $\mathrm{n} / \mathrm{a}$ & $\mathrm{n} / \mathrm{a}$ & $\mathrm{n} / \mathrm{a}$ & $\mathrm{n} / \mathrm{a}$ & $\mathrm{n} / \mathrm{a}$ & $\mathrm{n} / \mathrm{a}$ & $\mathrm{n} / \mathrm{a}$ \\
\hline 28 & 7 & -26.8 & 1.1 & 2 & $\mathrm{n} / \mathrm{a}$ & $\mathrm{n} / \mathrm{a}$ & $\mathrm{n} / \mathrm{a}$ & $\mathrm{n} / \mathrm{a}$ \\
\hline 29 & 105 & -29.1 & $\mathrm{n} / \mathrm{a}$ & 18 & $\mathrm{n} / \mathrm{a}$ & $\mathrm{n} / \mathrm{a}$ & $\mathrm{n} / \mathrm{a}$ & $\mathrm{n} / \mathrm{a}$ \\
\hline 30 & 93 & -28.5 & 1.2 & 107 & -26.4 & 0.5 & 19 & $\mathrm{n} / \mathrm{a}$ \\
\hline $\begin{array}{l}31 \\
32\end{array}$ & $\mathrm{n} / \mathrm{a}$ & $\mathrm{n} / \mathrm{a}$ & $\mathrm{n} / \mathrm{a}$ & $\mathrm{n} / \mathrm{a}$ & $\mathrm{n} / \mathrm{a}$ & $\mathrm{n} / \mathrm{a}$ & $\mathrm{n} / \mathrm{a}$ & $\mathrm{n} / \mathrm{a}$ \\
\hline $\begin{array}{l}32 \\
33\end{array}$ & $\mathrm{n} / \mathrm{a}$ & $\mathrm{n} / \mathrm{a}$ & $\mathrm{n} / \mathrm{a}$ & $\mathrm{n} / \mathrm{a}$ & $\mathrm{n} / \mathrm{a}$ & $\mathrm{n} / \mathrm{a}$ & $\mathrm{n} / \mathrm{a}$ & $\mathrm{n} / \mathrm{a}$ \\
\hline 34 & $\mathrm{n} / \mathrm{a}$ & $\mathrm{n} / \mathrm{a}$ & $\mathrm{n} / \mathrm{a}$ & $\mathrm{n} / \mathrm{a}$ & $\mathrm{n} / \mathrm{a}$ & $\mathrm{n} / \mathrm{a}$ & $\mathrm{n} / \mathrm{a}$ & $\mathrm{n} / \mathrm{a}$ \\
\hline 35 & 220 & $\mathrm{n} / \mathrm{a}$ & $\mathrm{n} / \mathrm{a}$ & $\mathrm{n} / \mathrm{a}$ & $\mathrm{n} / \mathrm{a}$ & $\mathrm{n} / \mathrm{a}$ & $\mathrm{n} / \mathrm{a}$ & $\mathrm{n} / \mathrm{a}$ \\
\hline 36 & 209 & $\mathrm{n} / \mathrm{a}$ & $\mathrm{n} / \mathrm{a}$ & $\mathrm{n} / \mathrm{a}$ & $\mathrm{n} / \mathrm{a}$ & $\mathrm{n} / \mathrm{a}$ & $\mathrm{n} / \mathrm{a}$ & $\mathrm{n} / \mathrm{a}$ \\
\hline 37 & 275 & $\mathrm{n} / \mathrm{a}$ & $\mathrm{n} / \mathrm{a}$ & $\mathrm{n} / \mathrm{a}$ & $\mathrm{n} / \mathrm{a}$ & $\mathrm{n} / \mathrm{a}$ & $\mathrm{n} / \mathrm{a}$ & $\mathrm{n} / \mathrm{a}$ \\
\hline 38 & 99 & $\mathrm{n} / \mathrm{a}$ & $\mathrm{n} / \mathrm{a}$ & $\mathrm{n} / \mathrm{a}$ & $\mathrm{n} / \mathrm{a}$ & $\mathrm{n} / \mathrm{a}$ & $\mathrm{n} / \mathrm{a}$ & $\mathrm{n} / \mathrm{a}$ \\
\hline $\begin{array}{l}39 \\
40\end{array}$ & 41 & $\mathrm{n} / \mathrm{a}$ & $\mathrm{n} / \mathrm{a}$ & $\mathrm{n} / \mathrm{a}$ & $\mathrm{n} / \mathrm{a}$ & $\mathrm{n} / \mathrm{a}$ & $\mathrm{n} / \mathrm{a}$ & $\mathrm{n} / \mathrm{a}$ \\
\hline
\end{tabular}




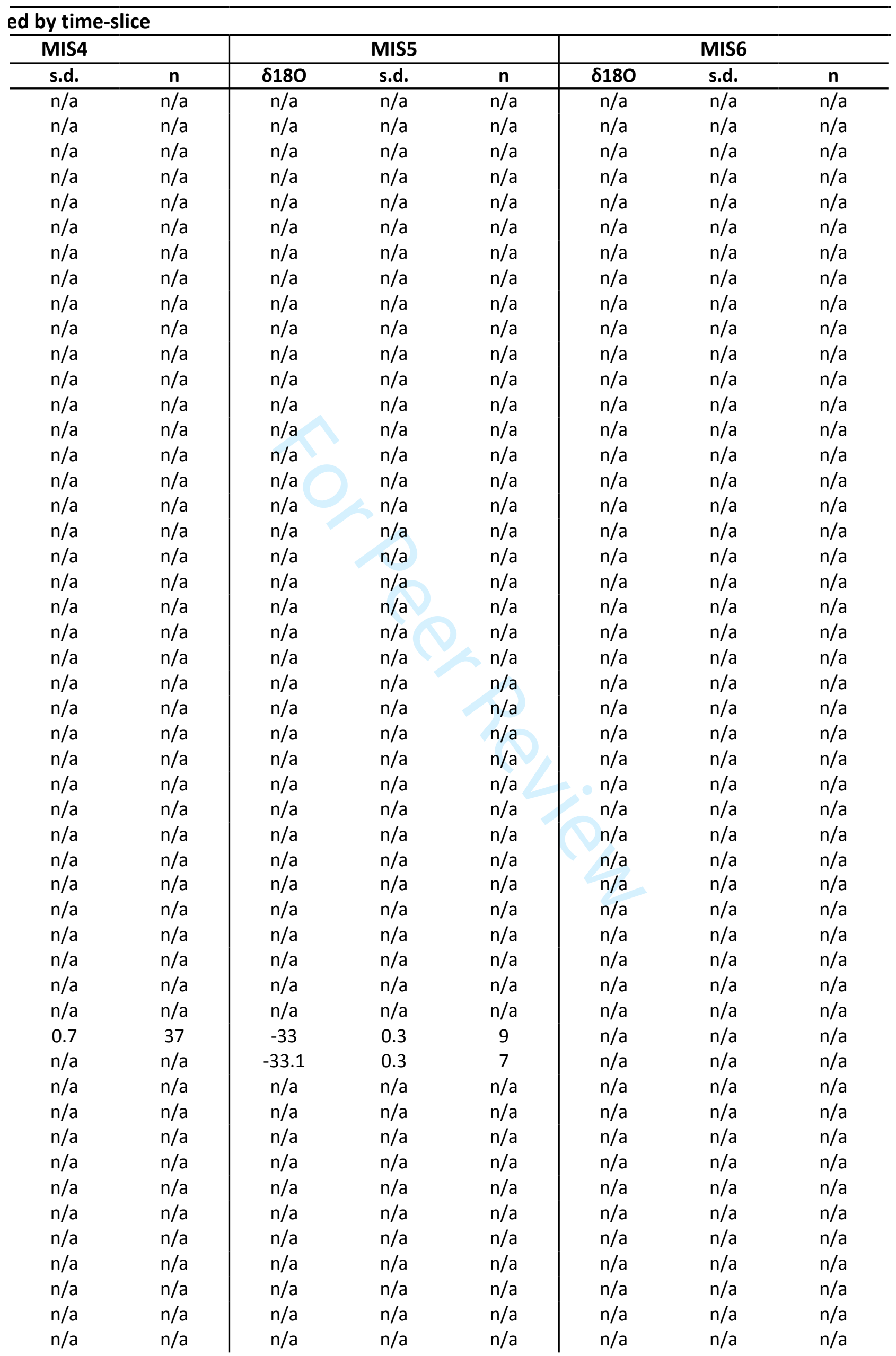




\begin{tabular}{|c|c|c|c|c|c|c|c|c|}
\hline 2 & $\mathrm{n} / \mathrm{a}$ & $\mathrm{n} / \mathrm{a}$ & $\mathrm{n} / \mathrm{a}$ & $\mathrm{n} / \mathrm{a}$ & $\mathrm{n} / \mathrm{a}$ & $\mathrm{n} / \mathrm{a}$ & $\mathrm{n} / \mathrm{a}$ & $\mathrm{n} / \mathrm{a}$ \\
\hline 3 & $\mathrm{n} / \mathrm{a}$ & $\mathrm{n} / \mathrm{a}$ & $\mathrm{n} / \mathrm{a}$ & $\mathrm{n} / \mathrm{a}$ & $\mathrm{n} / \mathrm{a}$ & $\mathrm{n} / \mathrm{a}$ & $\mathrm{n} / \mathrm{a}$ & $\mathrm{n} / \mathrm{a}$ \\
\hline 4 & $\mathrm{n} / \mathrm{a}$ & $\mathrm{n} / \mathrm{a}$ & $\mathrm{n} / \mathrm{a}$ & $\mathrm{n} / \mathrm{a}$ & $\mathrm{n} / \mathrm{a}$ & $\mathrm{n} / \mathrm{a}$ & $\mathrm{n} / \mathrm{a}$ & $\mathrm{n} / \mathrm{a}$ \\
\hline 5 & $\mathrm{n} / \mathrm{a}$ & $\mathrm{n} / \mathrm{a}$ & $\mathrm{n} / \mathrm{a}$ & $\mathrm{n} / \mathrm{a}$ & $\mathrm{n} / \mathrm{a}$ & $\mathrm{n} / \mathrm{a}$ & $\mathrm{n} / \mathrm{a}$ & $\mathrm{n} / \mathrm{a}$ \\
\hline 6 & $\mathrm{n} / \mathrm{a}$ & $\mathrm{n} / \mathrm{a}$ & $\mathrm{n} / \mathrm{a}$ & $\mathrm{n} / \mathrm{a}$ & $\mathrm{n} / \mathrm{a}$ & $\mathrm{n} / \mathrm{a}$ & $\mathrm{n} / \mathrm{a}$ & $\mathrm{n} / \mathrm{a}$ \\
\hline $\begin{array}{l}7 \\
8\end{array}$ & $\mathrm{n} / \mathrm{a}$ & $\mathrm{n} / \mathrm{a}$ & $\mathrm{n} / \mathrm{a}$ & $\mathrm{n} / \mathrm{a}$ & $\mathrm{n} / \mathrm{a}$ & $\mathrm{n} / \mathrm{a}$ & $\mathrm{n} / \mathrm{a}$ & $\mathrm{n} / \mathrm{a}$ \\
\hline $\begin{array}{l}8 \\
9\end{array}$ & $\mathrm{n} / \mathrm{a}$ & $\mathrm{n} / \mathrm{a}$ & $\mathrm{n} / \mathrm{a}$ & $\mathrm{n} / \mathrm{a}$ & $\mathrm{n} / \mathrm{a}$ & $\mathrm{n} / \mathrm{a}$ & $\mathrm{n} / \mathrm{a}$ & $\mathrm{n} / \mathrm{a}$ \\
\hline 10 & $\mathrm{n} / \mathrm{a}$ & $\mathrm{n} / \mathrm{a}$ & $\mathrm{n} / \mathrm{a}$ & $\mathrm{n} / \mathrm{a}$ & $\mathrm{n} / \mathrm{a}$ & $\mathrm{n} / \mathrm{a}$ & $\mathrm{n} / \mathrm{a}$ & $\mathrm{n} / \mathrm{a}$ \\
\hline 11 & $\mathrm{n} / \mathrm{a}$ & $\mathrm{n} / \mathrm{a}$ & $\mathrm{n} / \mathrm{a}$ & $\mathrm{n} / \mathrm{a}$ & $\mathrm{n} / \mathrm{a}$ & $\mathrm{n} / \mathrm{a}$ & $\mathrm{n} / \mathrm{a}$ & $\mathrm{n} / \mathrm{a}$ \\
\hline 12 & $\mathrm{n} / \mathrm{a}$ & $\mathrm{n} / \mathrm{a}$ & $\mathrm{n} / \mathrm{a}$ & $\mathrm{n} / \mathrm{a}$ & $\mathrm{n} / \mathrm{a}$ & $\mathrm{n} / \mathrm{a}$ & $\mathrm{n} / \mathrm{a}$ & $\mathrm{n} / \mathrm{a}$ \\
\hline 13 & $\mathrm{n} / \mathrm{a}$ & $\mathrm{n} / \mathrm{a}$ & $\mathrm{n} / \mathrm{a}$ & $\mathrm{n} / \mathrm{a}$ & $\mathrm{n} / \mathrm{a}$ & $\mathrm{n} / \mathrm{a}$ & $\mathrm{n} / \mathrm{a}$ & $\mathrm{n} / \mathrm{a}$ \\
\hline 14 & $\mathrm{n} / \mathrm{a}$ & $\mathrm{n} / \mathrm{a}$ & $\mathrm{n} / \mathrm{a}$ & $\mathrm{n} / \mathrm{a}$ & $\mathrm{n} / \mathrm{a}$ & $\mathrm{n} / \mathrm{a}$ & $\mathrm{n} / \mathrm{a}$ & $\mathrm{n} / \mathrm{a}$ \\
\hline $\begin{array}{l}15 \\
16\end{array}$ & $\mathrm{n} / \mathrm{a}$ & $\mathrm{n} / \mathrm{a}$ & $\mathrm{n} / \mathrm{a}$ & $\mathrm{n} / \mathrm{a}$ & $\mathrm{n} / \mathrm{a}$ & $\mathrm{n} / \mathrm{a}$ & $\mathrm{n} / \mathrm{a}$ & $\mathrm{n} / \mathrm{a}$ \\
\hline $\begin{array}{l}16 \\
17\end{array}$ & $\mathrm{n} / \mathrm{a}$ & $\mathrm{n} / \mathrm{a}$ & $\mathrm{n} / \mathrm{a}$ & $\mathrm{n} / \mathrm{a}$ & $\mathrm{n} / \mathrm{a}$ & $\mathrm{n} / \mathrm{a}$ & $\mathrm{n} / \mathrm{a}$ & $\mathrm{n} / \mathrm{a}$ \\
\hline 18 & $\mathrm{n} / \mathrm{a}$ & $\mathrm{n} / \mathrm{a}$ & $\mathrm{n} / \mathrm{a}$ & $\mathrm{n} / \mathrm{a}$ & $\mathrm{n} / \mathrm{a}$ & $\mathrm{n} / \mathrm{a}$ & $\mathrm{n} / \mathrm{a}$ & $\mathrm{n} / \mathrm{a}$ \\
\hline 19 & $\mathrm{n} / \mathrm{a}$ & $\mathrm{n} / \mathrm{a}$ & $\mathrm{n} / \mathrm{a}$ & $\mathrm{n} / \mathrm{a}$ & $\mathrm{n} / \mathrm{a}$ & $\mathrm{n} / \mathrm{a}$ & $\mathrm{n} / \mathrm{a}$ & $\mathrm{n} / \mathrm{a}$ \\
\hline 20 & $\mathrm{n} / \mathrm{a}$ & $\mathrm{n} / \mathrm{a}$ & $\mathrm{n} / \mathrm{a}$ & $\mathrm{n} / \mathrm{a}$ & $\mathrm{n} / \mathrm{a}$ & $\mathrm{n} / \mathrm{a}$ & $\mathrm{n} / \mathrm{a}$ & $\mathrm{n} / \mathrm{a}$ \\
\hline 21 & $\mathrm{n} / \mathrm{a}$ & $\mathrm{n} / \mathrm{a}$ & $\mathrm{n} / \mathrm{a}$ & $\mathrm{n} / \mathrm{a}$ & $\mathrm{n} / \mathrm{a}$ & $\mathrm{n} / \mathrm{a}$ & $\mathrm{n} / \mathrm{a}$ & $\mathrm{n} / \mathrm{a}$ \\
\hline 22 & $\mathrm{n} / \mathrm{a}$ & $\mathrm{n} / \mathrm{a}$ & $\mathrm{n} / \mathrm{a}$ & $\mathrm{n} / \mathrm{a}$ & $\mathrm{n} / \mathrm{a}$ & $\mathrm{n} / \mathrm{a}$ & $\mathrm{n} / \mathrm{a}$ & $\mathrm{n} / \mathrm{a}$ \\
\hline 23 & $\mathrm{n} / \mathrm{a}$ & $\mathrm{n} / \mathrm{a}$ & $\mathrm{n} / \mathrm{a}$ & $\mathrm{n} / \mathrm{a}$ & $\mathrm{n} / \mathrm{a}$ & $\mathrm{n} / \mathrm{a}$ & $\mathrm{n} / \mathrm{a}$ & $\mathrm{n} / \mathrm{a}$ \\
\hline $\begin{array}{l}24 \\
25\end{array}$ & $\mathrm{n} / \mathrm{a}$ & $\mathrm{n} / \mathrm{a}$ & $\mathrm{n} / \mathrm{a}$ & $\mathrm{n} / \mathrm{a}$ & $\mathrm{n} / \mathrm{a}$ & $\mathrm{n} / \mathrm{a}$ & $\mathrm{n} / \mathrm{a}$ & $\mathrm{n} / \mathrm{a}$ \\
\hline 26 & $\mathrm{n} / \mathrm{a}$ & $\mathrm{n} / \mathrm{a}$ & $\mathrm{n} / \mathrm{a}$ & $\mathrm{n} / \mathrm{a}$ & $\mathrm{n} / \mathrm{a}$ & $\mathrm{n} / \mathrm{a}$ & $\mathrm{n} / \mathrm{a}$ & $\mathrm{n} / \mathrm{a}$ \\
\hline 27 & $\mathrm{n} / \mathrm{a}$ & $\mathrm{n} / \mathrm{a}$ & $\mathrm{n} / \mathrm{a}$ & $\mathrm{n} / \mathrm{a}$ & $\mathrm{n} / \mathrm{a}$ & $\mathrm{n} / \mathrm{a}$ & $\mathrm{n} / \mathrm{a}$ & $\mathrm{n} / \mathrm{a}$ \\
\hline 28 & $\mathrm{n} / \mathrm{a}$ & $\mathrm{n} / \mathrm{a}$ & $\mathrm{n} / \mathrm{a}$ & $\mathrm{n} / \mathrm{a}$ & $\mathrm{n} / \mathrm{a}$ & $\mathrm{n} / \mathrm{a}$ & $\mathrm{n} / \mathrm{a}$ & $\mathrm{n} / \mathrm{a}$ \\
\hline 29 & $\mathrm{n} / \mathrm{a}$ & $\mathrm{n} / \mathrm{a}$ & $\mathrm{n} / \mathrm{a}$ & $\mathrm{n} / \mathrm{a}$ & $\mathrm{n} / \mathrm{a}$ & $\mathrm{n} / \mathrm{a}$ & $\mathrm{n} / \mathrm{a}$ & $\mathrm{n} / \mathrm{a}$ \\
\hline 30 & $\mathrm{n} / \mathrm{a}$ & $\mathrm{n} / \mathrm{a}$ & $\mathrm{n} / \mathrm{a}$ & $\mathrm{n} / \mathrm{a}$ & $\mathrm{n} / \mathrm{a}$ & $\mathrm{n} / \mathrm{a}$ & $\mathrm{n} / \mathrm{a}$ & $\mathrm{n} / \mathrm{a}$ \\
\hline 31 & $\mathrm{n} / \mathrm{a}$ & $\mathrm{n} / \mathrm{a}$ & $\mathrm{n} / \mathrm{a}$ & $\mathrm{n} / \mathrm{a}$ & $\mathrm{n} / \mathrm{a}$ & $\mathrm{n} / \mathrm{a}$ & $\mathrm{n} / \mathrm{a}$ & $\mathrm{n} / \mathrm{a}$ \\
\hline $\begin{array}{l}32 \\
33\end{array}$ & $\mathrm{n} / \mathrm{a}$ & $\mathrm{n} / \mathrm{a}$ & $\mathrm{n} / \mathrm{a}$ & $\mathrm{n} / \mathrm{a}$ & $\mathrm{n} / \mathrm{a}$ & $\mathrm{n} / \mathrm{a}$ & $\mathrm{n} / \mathrm{a}$ & $\mathrm{n} / \mathrm{a}$ \\
\hline 34 & $\mathrm{n} / \mathrm{a}$ & $\mathrm{n} / \mathrm{a}$ & $\mathrm{n} / \mathrm{a}$ & $\mathrm{n} / \mathrm{a}$ & $n / a$ & $\mathrm{n} / \mathrm{a}$ & $\mathrm{n} / \mathrm{a}$ & $\mathrm{n} / \mathrm{a}$ \\
\hline 35 & $\mathrm{n} / \mathrm{a}$ & $\mathrm{n} / \mathrm{a}$ & $\mathrm{n} / \mathrm{a}$ & $\mathrm{n} / \mathrm{a}$ & $\mathrm{n} / \mathrm{a}$ & $\mathrm{n} / \mathrm{a}$ & $\mathrm{n} / \mathrm{a}$ & $\mathrm{n} / \mathrm{a}$ \\
\hline 36 & $\mathrm{n} / \mathrm{a}$ & $\mathrm{n} / \mathrm{a}$ & $\mathrm{n} / \mathrm{a}$ & $\mathrm{n} / \mathrm{a}$ & $\mathrm{n} / \mathrm{a}$ & $\mathrm{n} / \mathrm{a}$ & $\mathrm{n} / \mathrm{a}$ & $\mathrm{n} / \mathrm{a}$ \\
\hline 37 & $\mathrm{n} / \mathrm{a}$ & $\mathrm{n} / \mathrm{a}$ & $\mathrm{n} / \mathrm{a}$ & $\mathrm{n} / \mathrm{a}$ & $\mathrm{n} / \mathrm{a}$ & $\mathrm{n} / \mathrm{a}$ & $\mathrm{n} / \mathrm{a}$ & $\mathrm{n} / \mathrm{a}$ \\
\hline 38 & $\mathrm{n} / \mathrm{a}$ & $\mathrm{n} / \mathrm{a}$ & $\mathrm{n} / \mathrm{a}$ & $\mathrm{n} / \mathrm{a}$ & $\mathrm{n} / \mathrm{a}$ & $\mathrm{n} / \mathrm{a}$ & $\mathrm{n} / \mathrm{a}$ & $\mathrm{n} / \mathrm{a}$ \\
\hline 39 & $\mathrm{n} / \mathrm{a}$ & $\mathrm{n} / \mathrm{a}$ & $\mathrm{n} / \mathrm{a}$ & $\mathrm{n} / \mathrm{a}$ & $\mathrm{n} / \mathrm{a}$ & $\mathrm{n} / \mathrm{a}$ & $\mathrm{n} / \mathrm{a}$ & $\mathrm{n} / \mathrm{a}$ \\
\hline
\end{tabular}




\begin{tabular}{|c|c|c|c|}
\hline \multicolumn{3}{|c|}{ MIS7 or older } & \multirow[b]{2}{*}{ Stated in cited papers } \\
\hline$\delta 180$ & s.d. & $n$ & \\
\hline $\mathrm{n} / \mathrm{a}$ & $\mathrm{n} / \mathrm{a}$ & $\mathrm{n} / \mathrm{a}$ & $x$ \\
\hline $\mathrm{n} / \mathrm{a}$ & $\mathrm{n} / \mathrm{a}$ & $\mathrm{n} / \mathrm{a}$ & $x$ \\
\hline$n / a$ & $\mathrm{n} / \mathrm{a}$ & $\mathrm{n} / \mathrm{a}$ & $\mathrm{n} / \mathrm{a}$ \\
\hline $\mathrm{n} / \mathrm{a}$ & $\mathrm{n} / \mathrm{a}$ & $\mathrm{n} / \mathrm{a}$ & $x$ \\
\hline$n / a$ & $\mathrm{n} / \mathrm{a}$ & $\mathrm{n} / \mathrm{a}$ & $x$ \\
\hline$n / a$ & $\mathrm{n} / \mathrm{a}$ & $\mathrm{n} / \mathrm{a}$ & $x$ \\
\hline$n / a$ & $\mathrm{n} / \mathrm{a}$ & $\mathrm{n} / \mathrm{a}$ & $x$ \\
\hline $\mathrm{n} / \mathrm{a}$ & $\mathrm{n} / \mathrm{a}$ & $\mathrm{n} / \mathrm{a}$ & $x$ \\
\hline $\mathrm{n} / \mathrm{a}$ & $\mathrm{n} / \mathrm{a}$ & $\mathrm{n} / \mathrm{a}$ & $x$ \\
\hline$n / a$ & $\mathrm{n} / \mathrm{a}$ & $\mathrm{n} / \mathrm{a}$ & $x$ \\
\hline$n / a$ & $\mathrm{n} / \mathrm{a}$ & $n / a$ & $x$ \\
\hline $\mathrm{n} / \mathrm{a}$ & $\mathrm{n} / \mathrm{a}$ & $\mathrm{n} / \mathrm{a}$ & $x$ \\
\hline $\mathrm{n} / \mathrm{a}$ & $\mathrm{n} / \mathrm{a}$ & $\mathrm{n} / \mathrm{a}$ & $x$ \\
\hline$n / a$ & $\mathrm{n} / \mathrm{a}$ & $\mathrm{n} / \mathrm{a}$ & $x$ \\
\hline $\mathrm{n} / \mathrm{a}$ & $\mathrm{n} / \mathrm{a}$ & $\mathrm{n} / \mathrm{a}$ & $\mathrm{n} / \mathrm{a}$ \\
\hline $\mathrm{n} / \mathrm{a}$ & $\mathrm{n} / \mathrm{a}$ & $\mathrm{n} / \mathrm{a}$ & $\mathrm{x}$ \\
\hline $\mathrm{n} / \mathrm{a}$ & $\mathrm{n} / \mathrm{a}$ & $\mathrm{n} / \mathrm{a}$ & $x$ \\
\hline $\mathrm{n} / \mathrm{a}$ & $\mathrm{n} / \mathrm{a}$ & $\mathrm{n} / \mathrm{a}$ & $x$ \\
\hline $\mathrm{n} / \mathrm{a}$ & $\mathrm{n} / \mathrm{a}$ & $\mathrm{n} / \mathrm{a}$ & $x$ \\
\hline $\mathrm{n} / \mathrm{a}$ & $\mathrm{n} / \mathrm{a}$ & $\mathrm{n} / \mathrm{a}$ & $x$ \\
\hline $\mathrm{n} / \mathrm{a}$ & $\mathrm{n} / \mathrm{a}$ & $\mathrm{n} / \mathrm{a}$ & $x$ \\
\hline$n / a$ & $\mathrm{n} / \mathrm{a}$ & $\mathrm{n} / \mathrm{a}$ & $x$ \\
\hline$n / a$ & $\mathrm{n} / \mathrm{a}$ & $n / a$ & $x$ \\
\hline $\mathrm{n} / \mathrm{a}$ & $\mathrm{n} / \mathrm{a}$ & $\mathrm{n} / \mathrm{a}$ & $x$ \\
\hline $\mathrm{n} / \mathrm{a}$ & $\mathrm{n} / \mathrm{a}$ & $\mathrm{n} / \mathrm{a}$ & $x$ \\
\hline$n / a$ & $\mathrm{n} / \mathrm{a}$ & $\mathrm{n} / \mathrm{a}$ & $x$ \\
\hline $\mathrm{n} / \mathrm{a}$ & $\mathrm{n} / \mathrm{a}$ & $\mathrm{n} / \mathrm{a}$ & $x$ \\
\hline$n / a$ & $\mathrm{n} / \mathrm{a}$ & $\mathrm{n} / \mathrm{a}$ & $x$ \\
\hline $\mathrm{n} / \mathrm{a}$ & $\mathrm{n} / \mathrm{a}$ & $\mathrm{n} / \mathrm{a}$ & $x$ \\
\hline-33.1 & 0.1 & 6 & $x$ \\
\hline $\mathrm{n} / \mathrm{a}$ & $\mathrm{n} / \mathrm{a}$ & $\mathrm{n} / \mathrm{a}$ & $x$ \\
\hline $\mathrm{n} / \mathrm{a}$ & $\mathrm{n} / \mathrm{a}$ & $\mathrm{n} / \mathrm{a}$ & $x$ \\
\hline$n / a$ & $\mathrm{n} / \mathrm{a}$ & $\mathrm{n} / \mathrm{a}$ & $x$ \\
\hline$n / a$ & $\mathrm{n} / \mathrm{a}$ & $\mathrm{n} / \mathrm{a}$ & $x$ \\
\hline$n / a$ & $\mathrm{n} / \mathrm{a}$ & $\mathrm{n} / \mathrm{a}$ & $x$ \\
\hline$n / a$ & $\mathrm{n} / \mathrm{a}$ & $\mathrm{n} / \mathrm{a}$ & $n / a$ \\
\hline $\mathrm{n} / \mathrm{a}$ & $\mathrm{n} / \mathrm{a}$ & $\mathrm{n} / \mathrm{a}$ & $\mathrm{n} / \mathrm{a}$ \\
\hline-31.8 & 1.25 & 56 & $x$ \\
\hline $\mathrm{n} / \mathrm{a}$ & $\mathrm{n} / \mathrm{a}$ & $\mathrm{n} / \mathrm{a}$ & $x$ \\
\hline $\mathrm{n} / \mathrm{a}$ & $\mathrm{n} / \mathrm{a}$ & $\mathrm{n} / \mathrm{a}$ & $x$ \\
\hline$n / a$ & $\mathrm{n} / \mathrm{a}$ & $\mathrm{n} / \mathrm{a}$ & $x$ \\
\hline $\mathrm{n} / \mathrm{a}$ & $\mathrm{n} / \mathrm{a}$ & $\mathrm{n} / \mathrm{a}$ & $x$ \\
\hline $\mathrm{n} / \mathrm{a}$ & $\mathrm{n} / \mathrm{a}$ & $\mathrm{n} / \mathrm{a}$ & $x$ \\
\hline $\mathrm{n} / \mathrm{a}$ & $\mathrm{n} / \mathrm{a}$ & $\mathrm{n} / \mathrm{a}$ & $x$ \\
\hline $\mathrm{n} / \mathrm{a}$ & $\mathrm{n} / \mathrm{a}$ & $\mathrm{n} / \mathrm{a}$ & $x$ \\
\hline $\mathrm{n} / \mathrm{a}$ & $\mathrm{n} / \mathrm{a}$ & $\mathrm{n} / \mathrm{a}$ & $x$ \\
\hline $\mathrm{n} / \mathrm{a}$ & $\mathrm{n} / \mathrm{a}$ & $\mathrm{n} / \mathrm{a}$ & $\mathrm{n} / \mathrm{a}$ \\
\hline $\mathrm{n} / \mathrm{a}$ & $\mathrm{n} / \mathrm{a}$ & $\mathrm{n} / \mathrm{a}$ & $x$ \\
\hline $\mathrm{n} / \mathrm{a}$ & $\mathrm{n} / \mathrm{a}$ & $\mathrm{n} / \mathrm{a}$ & $x$ \\
\hline$n / a$ & $\mathrm{n} / \mathrm{a}$ & $\mathrm{n} / \mathrm{a}$ & $n / a$ \\
\hline
\end{tabular}




\begin{tabular}{|c|c|c|c|c|}
\hline 1 & $n / a$ & $n / a$ & $\mathrm{n} / \mathrm{a}$ & $x$ \\
\hline 3 & $\mathrm{n} / \mathrm{a}$ & $\mathrm{n} / \mathrm{a}$ & $\mathrm{n} / \mathrm{a}$ & $x$ \\
\hline 4 & $\mathrm{n} / \mathrm{a}$ & $\mathrm{n} / \mathrm{a}$ & $\mathrm{n} / \mathrm{a}$ & $x$ \\
\hline 5 & $\mathrm{n} / \mathrm{a}$ & $\mathrm{n} / \mathrm{a}$ & $\mathrm{n} / \mathrm{a}$ & $x$ \\
\hline 6 & $\mathrm{n} / \mathrm{a}$ & $\mathrm{n} / \mathrm{a}$ & $\mathrm{n} / \mathrm{a}$ & $x$ \\
\hline 7 & $\mathrm{n} / \mathrm{a}$ & $\mathrm{n} / \mathrm{a}$ & $\mathrm{n} / \mathrm{a}$ & $x$ \\
\hline $\begin{array}{l}8 \\
9\end{array}$ & $\mathrm{n} / \mathrm{a}$ & $\mathrm{n} / \mathrm{a}$ & $\mathrm{n} / \mathrm{a}$ & $x$ \\
\hline 10 & $\mathrm{n} / \mathrm{a}$ & $\mathrm{n} / \mathrm{a}$ & $\mathrm{n} / \mathrm{a}$ & $x$ \\
\hline 11 & $\mathrm{n} / \mathrm{a}$ & $\mathrm{n} / \mathrm{a}$ & $\mathrm{n} / \mathrm{a}$ & $x$ \\
\hline 12 & $\mathrm{n} / \mathrm{a}$ & $\mathrm{n} / \mathrm{a}$ & $\mathrm{n} / \mathrm{a}$ & $\mathrm{n} / \mathrm{a}$ \\
\hline 13 & $\mathrm{n} / \mathrm{a}$ & $\mathrm{n} / \mathrm{a}$ & $\mathrm{n} / \mathrm{a}$ & $x$ \\
\hline 14 & $\mathrm{n} / \mathrm{a}$ & $\mathrm{n} / \mathrm{a}$ & $\mathrm{n} / \mathrm{a}$ & $x$ \\
\hline $\begin{array}{l}15 \\
16\end{array}$ & $\mathrm{n} / \mathrm{a}$ & $\mathrm{n} / \mathrm{a}$ & $\mathrm{n} / \mathrm{a}$ & $x$ \\
\hline $\begin{array}{l}10 \\
17\end{array}$ & $\mathrm{n} / \mathrm{a}$ & $\mathrm{n} / \mathrm{a}$ & $\mathrm{n} / \mathrm{a}$ & $x$ \\
\hline 18 & $\mathrm{n} / \mathrm{a}$ & $\mathrm{n} / \mathrm{a}$ & $\mathrm{n} / \mathrm{a}$ & $x$ \\
\hline 19 & $\mathrm{n} / \mathrm{a}$ & $\mathrm{n} / \mathrm{a}$ & $\mathrm{n} / \mathrm{a}$ & $\mathrm{n} / \mathrm{a}$ \\
\hline 20 & $\mathrm{n} / \mathrm{a}$ & $\mathrm{n} / \mathrm{a}$ & $\mathrm{n} / \mathrm{a}$ & $x$ \\
\hline 21 & $\mathrm{n} / \mathrm{a}$ & $\mathrm{n} / \mathrm{a}$ & $\mathrm{n} / \mathrm{a}$ & $x$ \\
\hline 22 & $\mathrm{n} / \mathrm{a}$ & $\mathrm{n} / \mathrm{a}$ & $\mathrm{n} / \mathrm{a}$ & $\mathrm{n} / \mathrm{a}$ \\
\hline 23 & $\mathrm{n} / \mathrm{a}$ & $\mathrm{n} / \mathrm{a}$ & $\mathrm{n} / \mathrm{a}$ & $x$ \\
\hline $\begin{array}{l}24 \\
25\end{array}$ & $\mathrm{n} / \mathrm{a}$ & $\mathrm{n} / \mathrm{a}$ & $\mathrm{n} / \mathrm{a}$ & $\mathrm{n} / \mathrm{a}$ \\
\hline 26 & $\mathrm{n} / \mathrm{a}$ & $\mathrm{n} / \mathrm{a}$ & $\mathrm{n} / \mathrm{a}$ & $x$ \\
\hline 27 & $\mathrm{n} / \mathrm{a}$ & $\mathrm{n} / \mathrm{a}$ & $\mathrm{n} / \mathrm{a}$ & $\mathrm{n} / \mathrm{a}$ \\
\hline 28 & $\mathrm{n} / \mathrm{a}$ & $\mathrm{n} / \mathrm{a}$ & $\mathrm{n} / \mathrm{a}$ & $\mathrm{n} / \mathrm{a}$ \\
\hline 29 & $\mathrm{n} / \mathrm{a}$ & $\mathrm{n} / \mathrm{a}$ & $\mathrm{n} / \mathrm{a}$ & $x$ \\
\hline 30 & $\mathrm{n} / \mathrm{a}$ & $\mathrm{n} / \mathrm{a}$ & $\mathrm{n} / \mathrm{a}$ & $x$ \\
\hline $\begin{array}{l}31 \\
32\end{array}$ & $\mathrm{n} / \mathrm{a}$ & $\mathrm{n} / \mathrm{a}$ & $\mathrm{n} / \mathrm{a}$ & $\mathrm{n} / \mathrm{a}$ \\
\hline $\begin{array}{l}32 \\
33\end{array}$ & $\mathrm{n} / \mathrm{a}$ & $\mathrm{n} / \mathrm{a}$ & $\mathrm{n} / \mathrm{a}$ & $\mathrm{n} / \mathrm{a}$ \\
\hline 34 & $\mathrm{n} / \mathrm{a}$ & $\mathrm{n} / \mathrm{a}$ & $\mathrm{n} / \mathrm{a}$ & $\mathrm{n} / \mathrm{a}$ \\
\hline 35 & $\mathrm{n} / \mathrm{a}$ & $\mathrm{n} / \mathrm{a}$ & $\mathrm{n} / \mathrm{a}$ & $x$ \\
\hline 36 & $\mathrm{n} / \mathrm{a}$ & $\mathrm{n} / \mathrm{a}$ & $\mathrm{n} / \mathrm{a}$ & $x$ \\
\hline 37 & $\mathrm{n} / \mathrm{a}$ & $\mathrm{n} / \mathrm{a}$ & $\mathrm{n} / \mathrm{a}$ & $x$ \\
\hline 38 & $\mathrm{n} / \mathrm{a}$ & $\mathrm{n} / \mathrm{a}$ & $\mathrm{n} / \mathrm{a}$ & $x$ \\
\hline 39 & $\mathrm{n} / \mathrm{a}$ & $\mathrm{n} / \mathrm{a}$ & $\mathrm{n} / \mathrm{a}$ & $x$ \\
\hline
\end{tabular}




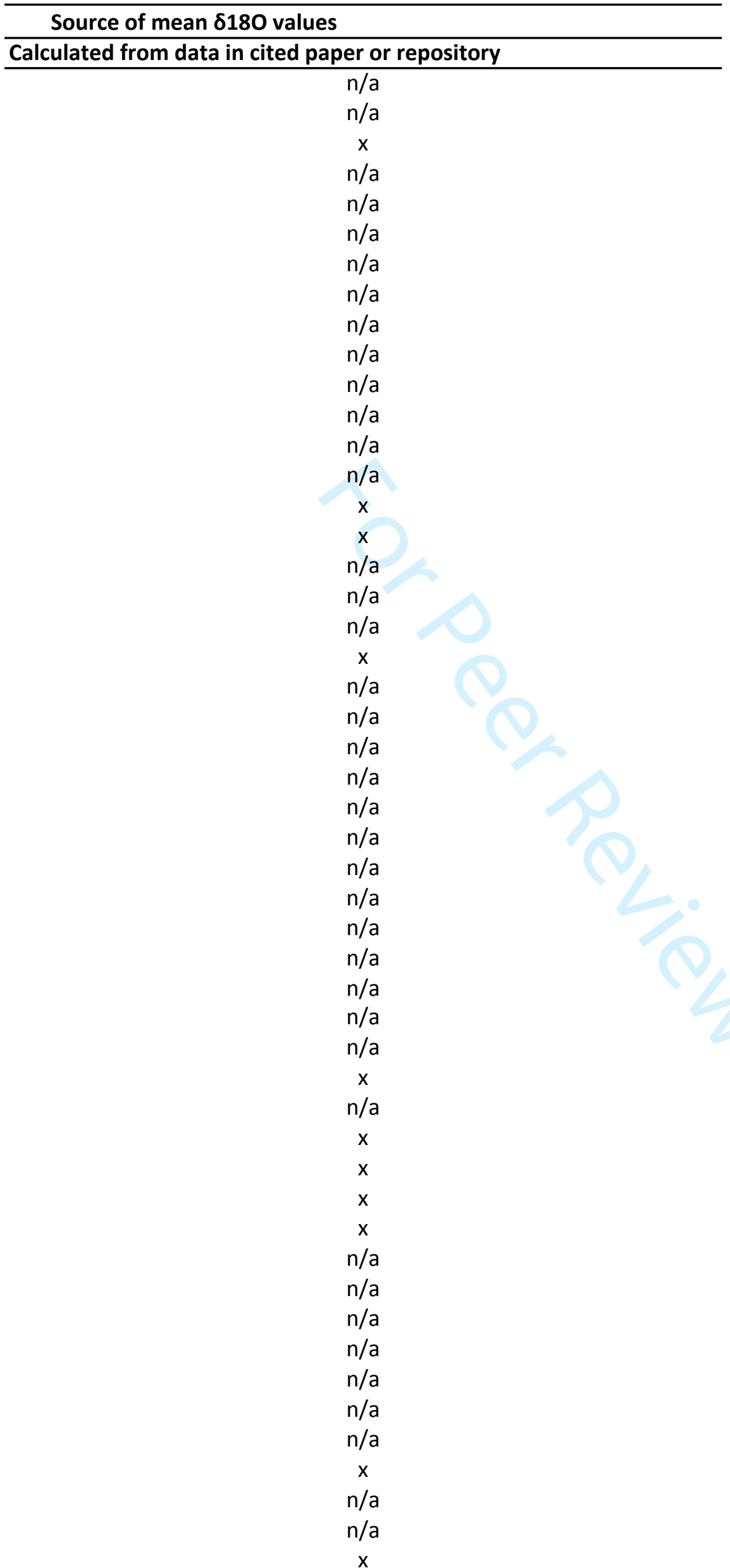


$n / a$

$n / a$

$\mathrm{n} / \mathrm{a}$

$\mathrm{n} / \mathrm{a}$

$x$

$x$

$n / a$

$n / a$

$n / a$

$x$

$n / a$

$\mathrm{n} / \mathrm{a}$

$n / a$

$x$

$n / a$

$\mathrm{x}$

n/a

$n / a$

$n / a$

$n / a$

$x$

n/a

$x$

$x$

$x$

$x$

$n / a$

$x$

$n / a$

$n / a$

$n / a$

$n / a$

$n / a$

$\mathrm{x}$ 


\section{Citations (First author, year, DOI/Journal)}

Streletskaya, 2015, Earth's Cryosphere

Streletskaya, 2015, Earth's Cryosphere

Vasil'chuk, 2015, Geography Environment Sustainability; Streletskaya, 2015, Earth's Cryosphere

Streletskaya, 2015, Earth's Cryosphere

Vasil'chuk, 2014, 10.1111/bor.12033; Streletskaya, 2015, Earth's Cryosphere

Streletskaya, 2015, Earth's Cryosphere

Vasil'chuk, 2014, 10.1111/bor.12033

Streletskaya, 2015, Earth's Cryosphere

Streletskaya, 2011, 10.1002/ppp.707; Streletskaya, 2015, Earth's Cryosphere

Streletskaya, 2011, 10.1002/ppp.707

Streletskaya, 2011, 10.1002/ppp.707; Streletskaya, 2015, Earth's Cryosphere

Wetterich, 2011, 10.1016/j.quascirev.2011.07.020; Vasil'chuk, 2014, 10.1111/bor.12033; Streletskaya, 2015, E Wetterich, 2011, 10.1016/j.quascirev.2011.07.020; Streletskaya, 2015, Earth's Cryosphere; Vasil'chuk, 2014, 1 Wetterich, 2011, 10.1016/j.quascirev.2011.07.020; Boereboom, 2013, 10.5194/tc-7-31-2013; Dereviagin, 201: Vasil'chuk, 2018, 10.1016/j.gsf.2017.04.008

Streletskaya, 2015, Earth's Cryosphere; Opel, 2019, 10.5194/cp-15-1443-2019

Schirrmeister, 2011, 10.1016/j.palaeo.2010.10.045

Schirrmeister, 2011, 10.1016/j.palaeo.2010.10.045; Opel, 2019, 10.5194/cp-15-1443-2019

Vasil'chuk, 2014, 10.1111/bor.12033

Meyer, 2015, 10.1038/NGEO2349

Opel, 2019, 10.5194/cp-15-1443-2019

Opel, 2019, 10.5194/cp-15-1443-2019

Wetterich, 2011, 10.1016/j.quascirev.2011.07.020; Streletskaya, 2015, Earth's Cryosphere; Opel, 2019, 10.519 Opel, 2019, 10.5194/cp-15-1443-2019

Kim, 2019, 10.1002/ppp.1994

Opel, 2019, 10.5194/cp-15-1443-2019

Vasil'chuk, 2014, 10.1111/bor.12033

Schirrmeister, 2017, 10.5194/bg-14-1261-2017; Opel, 2019, 10.5194/cp-15-1443-2019

Vasil'chuk, 2019, 10.1134/S1028334X19050283; Vasil'chuk, 2014, 10.1111/bor.12033; Opel, 2019, 10.5194/cp

Opel, 2019, 10.5194/cp-15-1443-2019; Vasil'chuk, 2017, 10.7256/2453-8922.2017.3.24433

Opel, 2019, 10.5194/cp-15-1443-2019

Opel, 2019, 10.5194/cp-15-1443-2019

Opel, 2019, 10.5194/cp-15-1443-2019

Vasil'chuk, 2018, 10.1134/S1028334X18090192

Opel, 2019, 10.5194/cp-15-1443-2019; Vasil'chuk, 2014, 10.1111/bor.12033

Vasil'chuk, 2018, 10.1134/S1028334X18090192; Streletskaya, 2015, Earth's Cryosphere

Vasil'chuk, 2018, 10.1134/S1028334X18090192

Wetterich, 2011, 10.1016/j.quascirev.2011.07.020; Wetterich, 2014, 10.1016/j.quascirev.2013.11.009; Strelet Opel, 2011, 10.1002/ppp.667; Streletskaya, 2015, Earth's Cryosphere; Opel, 2017, 10.1177/095968361770222

Opel, 2019, 10.5194/cp-15-1443-2019

Iwahana, 2014, 10.1016/j.polar.2014.01.005

Iwahana, 2014, 10.1016/j.polar.2014.01.005

Vasil'chuk, 2014, 10.1111/bor.12033

Streletskaya, 2015, Earth's Cryosphere

Vasil'chuk, 2014, 10.1111/bor.12033

Murton, 2015, 10.1002/ppp.1843; Vasil'chuk, 2014, 10.1111/bor.12033; Opel, 2019, 10.5194/cp-15-1443-201. Vasil'chuk, 2018, 10.21782/EC2541-9994-2018-5(3-16); Vasil'chuk, 2014, 10.1111/bor.12033; Streletskaya, 20 Vasil'chuk, 2014, 10.1111/bor.12033

Wetterich, 2018, 10.1002/ppp.1979

Vasil'chuk, 2018, 10.7256/2453-8922.2018.3.27121 
Streletskaya, 2015, Earth's Cryosphere Vasil'chuk, 2014, 10.1111/bor.12033

Streletskaya, 2015, Earth's Cryosphere Streletskaya, 2015, Earth's Cryosphere Vasil'chuk, 2018, 10.3103/S0145875218010131; Vasil'chuk, 2014, 10.1111/bor.12033 Vasil'chuk, 2017, 10.21782/EC1560-7496-2017-5(24-35); Vasil'chuk, 2014, 10.1111/bor.12033 Vasil'chuk, 2018, 10.1002/ppp.1991 Vasil'chuk, 2018, 10.1002/ppp.1991 Vasil'chuk, 2018, 10.1002/ppp.1991 Vasil'chuk, 2015, GEOGRAPHY ENVIRONMENT SUSTAINABILITY; Streletskaya, 2015, Earth's Cryosphere Wetterich, 2019, 10.5194/bg-16-4261-2019 Yang, 2011, 10.1007/s11430-010-4029-5 Brosius, 2012, 10.1029/2011JG001810 Meyer, 2010, 10.1029/2009GL041013; Meyer, 2010, 10.1016/j.quascirev.2010.08.005; lizuka, 2019, 10.1016/j Lapointe, 2017, 10.1016/j.palaeo.2017.08.006 Kanevskiy, 2017, 10.1016/j.geomorph.2017.09.001

Schirrmeister, 2016, 10.1016/j.quascirev.2016.02.009; St-Jean, 2011, 10.1002/ppp.680 Brosius, 2012, 10.1029/2011JG001810

Lachniet, 2012, 10.1016/j.yqres.2012.05.007; Lachniet, 2016, 10.1002/2016WR019436 Fritz, 2012, 10.1016/j.palaeo.2011.12.015

St-Jean, 2011, 10.1002/ppp.680

Calmels, 2012, 10.1139/E2012-023; Porter, 2016, 10.1016/j.quascirev.2016.02.006

Fritz, 2015, 10.5194/tc-9-737-2015

Fritz, 2015, 10.5194/tc-9-737-2015

Fritz, 2012, 10.1016/j.palaeo.2011.12.015; Fritz, 2016, 10.1016/j.quascirev.2016.02.00

St-Jean, 2011, 10.1002/ppp.680; Grinter, 2018, 10.1017/qua.2018.65

Porter, 2019, 10.1038/s41467-019-09622-y

Michel, 2011, 10.1002/ppp.721

Lacelle, 2014, 10.1016/j.chemgeo.2014.01.005

Holland, 2019, under review

Holland, 2019, under review

Holland, 2019, under review

Holland, 2019, under review

Coulombe, 2019, 10.5194/tc-13-97-2019 